\section{Does stock market capitalization cause GDP? A causality study for Central and Eastern European countries}

\author{
María A. Prats and Beatriz Sandoval
}

\begin{abstract}
This paper analyzes the relationship between stock market capitalization to GDP and real GDP in 10 Central and Eastern European countries (CEECs) that joined the European Union in 2004 and 2007, with the objective of determining whether the financial markets played a role as drivers of economic development in these countries or vice versa. The methodology, using a cointegrated Vector Autoregressive (VAR) model, is based on the application of three different measures of causality: Granger causality test, TodaYamamoto approach and Frequency Domain approach. The results obtained suggest evidence of a causal relationship in both directions between the variables in a significant number of countries, and especially in those where the variables show to be clearly cointegrated (Bulgaria, Hungary, Latvia, Romania, Slovakia and Slovenia).

(Published in Special Issue Recent developments in international economics)
\end{abstract}

JEL C32 F43 G15

Keywords Stock market development; economic growth; Granger causality; TodaYamamoto; frequency domain

\section{Authors}

María A. Prats, University of Murcia, Murcia, Spain, mprats@um.es

Beatriz Sandoval, University of Murcia, Murcia, Spain, beatriz.sandoval@um.es

Citation María A. Prats and Beatriz Sandoval (2020). Does stock market capitalization cause GDP? A causality study for Central and Eastern European countries. Economics: The Open-Access, Open-Assessment E-Journal, 14 (2020-17): 129. http://dx.doi.org/10.5018/economics-ejournal.ja.2020-17 


\section{Introduction}

The possibility that the financial sector affects and stimulates the real and productive sector of an economy and its growth generates a wide debate. As Levine (1997) pointed out, economic growth could be affected through the functions of financial markets via the channels of capital accumulation and technological innovation. Therefore, the analysis of the relationship between financial and economic variables arouses great interest in empirical literature (King and Levine, 1993; Levine and Zervos, 1998).

Among the different financial markets, the stock market is very relevant due to three fundamental reasons: the liquidity which it provides to financial assets, the important capital inflows it channels and the fact that it is a very useful source of information for investors (Wachtel, 2003). Therefore, the development of the stock market could potentially contribute to economic growth (Levine and Zervos, 1996; Caporale et al., 2004; Caporale and Spagnolo, 2012) and be, in itself, an economic policy objective. The role played in the financial system by the securities markets (including the stock markets) and by the banks has generated over time an intense debate about which of the two aspects causes greater economic growth. These two currents have led to the analysis of the main determinants on two different fronts: the marketbased and the bank-based. In this paper, we will only focus on aspects related to the importance of stock markets.

"Stock markets are the most developed market segment in emerging Europe" (Iorgova and Ong, 2008, p.8). In this context, the transitioning economies and the Central and Eastern European countries (CEECs) integrated into the European Union (EU) in 2004 (Czechia, Hungary, Poland, Estonia, Latvia, Lithuania, Slovenia and Slovakia) and in 2007 (Bulgaria and Romania), could be an interesting case study. These former communist economies had to develop an important transition process to become market economies. After the fall of the Berlin Wall in 1989 and until the mid-1990s, most CEECs began to open their stock markets and resumed stock market activity interrupted during the communist era. In relation to the stock markets of these countries, the Ljubljana (Slovenia) Stock Exchange was the first to open its market in 1990, followed by Budapest (Hungary); Warsaw (Poland) in 1991; Sofia (Bulgaria) in 1992; Bratislava (Slovakia), Prague (Czechia) and Vilnius (Lithuania) in 1993; Bucharest (Romania) and Riga (Latvia) in 1995; and, finally, Tallinn (Estonia) in 1996.

The three main countries in the Central and Eastern European region -Poland, Hungary and Czechia- "have the most developed stock, bond and derivatives markets, in terms of size, liquidity and instruments" (Iorgova and Ong, 2008, p.6). In addition, it is precisely in these countries where there are significant numbers of shares held by foreigners (Bonin and Wachtel, 2003). In all these countries, the stock market imposes requirements to guarantee a minimum liquidity to the number of shareholders and for the free float criteria (normally 25\%) (see Köke and Schröder, 2003).

In general, the emergence of the different stock markets was closely related to the privatization process through which property rights were distributed among citizens. In Bulgaria, Czechia, Lithuania, Slovakia and Romania, the privatization process was especially intense due to the liquidity problems of public companies. In Estonia, Hungary, Latvia, Poland and Slovenia, a limited number of stocks were offered by IPOs (Initial Public Offering) and, as a consequence, were traded more liquidly (Claessens et al., 2000). In precisely those countries 
where the privatization process went farthest, the ratio of market capitalization to GDP was the highest (Bonin and Wachtel, 2003).

The evolution of stock market capitalization to GDP, as shown in Annex 1, presents behavior in accordance with the most important events to which the market was subjected. The global stock market crisis, which began in 2000, generated a drop in the behavior of the stock market capitalization to GDP in the economies in transition as well as due to more stringent inclusion requirements and the tendency to concentrate property (Pajuste, 2002). The liberalization process in CEECs economies was subsequently encouraged by the process of European integration, generating a doubly expansive impulse. On the one hand, since the beginning of their transition to market economies, the CEECs have experienced significant rates of economic growth and convergence with the rest of the EU members and, on the other, their stock markets have been transformed. The incorporation of these transitioning economies into the European Union (EU) favored a real improvement in the stock market capitalization to GDP. In contrast, this ratio has been negatively affected by the financial crisis and the Great Recession, which began in 2008.

The purpose of this paper is to analyze the causal relationship between stock market capitalization to GDP (variable denoting stock market development) and real GDP (variable that measures economic activity) using a Vector Autoregressive model (VAR) in ten Central and Eastern European countries (Bulgaria, Czechia, Estonia, Hungary, Latvia, Lithuania, Poland, Romania, Slovakia and Slovenia). The analysis was carried out with the highest number of observations available for each country ranging from 1995 to 2017.

The main contribution of this paper is the use of the analysis of three different causality measures (Granger causality test, Frequency Domain approach and Toda-Yamamoto approach) for the study of the relationship between stock market development and the GDP of the CEECs, which has not been previously carried out in the empirical literature for all these countries. Other studies, such as Caporale and Spagnolo (2012) and Pece (2015), used a single method to study causality, making their results less robust. Our results will show whether the stock market played an important role in the economic activity of the CEECs. Logically, the stock market is expected to contribute significantly to the economic activity of these countries. Our results could also be important for policy makers and regulators in facilitating economic growth.

This paper is structured as follows. Section 2 discusses the literature. Section 3 explains the methodology and presents the data. In section 4, the empirical analysis is carried out, and the results of the empirical model are presented. Finally, section 5 concludes the paper.

\section{Literature review}

The relationship between economic activity and financial development is a topic that has been widely researched in economic debate. It is very important for policy makers to understand the possible role of the financial system in economic growth and how the functions of the financial system are linked to economic growth.

Goldsmith (1969) was one of the first authors to empirically demonstrate the connection between financial development and economic growth by using the value of assets intermediated 
as a percentage of GDP as a proxy for financial development. Using a sample of 80 countries from 1960 to 1989, King and Levine (1993) found that the development of the financial sector had a strong correlation with economic growth, improvements in the efficiency of capital allocation and the rate of physical capital accumulation. Furthermore, financial development was a good predictor of long-term growth; in countries with high levels of financial development, they found that economic growth tended to be relatively fast, specifically over the next 10 to 30 years.

There is a wide debate in the literature as to whether bank-based financial systems stimulate economic growth more than market-based financial systems and vice versa (Demirgüç-Kunt and Levine, 2001; Levine, 2002, 2005). There is another group of authors who maintain that the two aspects of the financial system, bank-based and market-based, are complementary and both contribute to economic growth. Levine and Zervos (1998) suggested that bank development and stock market development were simultaneously good predictors of economic growth, capital accumulation and productivity growth in a sample of 47 countries from 1976 until 1993.

In the context of intervened economies, any of the above disquisitions are useless because of government intervention, including in financial areas. In particular, for financial markets, government intervention implies a restriction on the mobilization of savings, investment and economic growth (McKinnon, 1973; Shaw, 1973). These authors developed the well-known Hypothesis of Financial Liberalization, according to which the financial system must be liberalized, and financing must be determined by the free play of the market. ${ }^{1}$ This hypothesis was later criticized by the Asymmetric Information Theory (Stiglitz and Weiss, 1981) and fundamentally by King and Levine (1993) who showed the existence of two ways by which causality exists between economic growth and the financial development of a country. On the one hand, a country with financial development of its stock markets can stimulate and promote economic growth and this, in turn, will create greater demand for financial services. If, on the other hand, financial institutions respond effectively to that demand, economic change is assured. From this point of view, both financial development and economic growth are interdependent, and their relationship generates causal feedback.

The relationship between stock market development and GDP has been studied empirically by many authors. By using the data of 41 countries over the period 1976-1993 in a crosscountry instrumental variables estimation, Levine and Zervos (1996) demonstrated that stock market development is positively related to long-term economic growth. Economic growth is measured by real per capita growth rate. Stock market development is measured by indicators of size, liquidity and risk diversification. In a later study, Levine and Zervos (1998), using the cross-country data of 47 countries from 1976 to 1993, found that stock market liquidity (turnover and value traded) and banking development (bank credit) were predictors of future economic growth, capital accumulation and productivity growth.

Mauro (2003) found a positive correlation between economic growth (measured by output growth) and stock returns (obtained as the difference between nominal stock returns and consumer price inflation) in ten out of 17 developed countries and five out of eight developing countries, with at least 20 observations and individual-countries regressions. Therefore, the result was stronger in developing countries. From a sample of seven countries (Argentina, Chile,

\footnotetext{
${ }^{1}$ For an in-depth review of the Financial Liberalization Theory, see Gemech and Struthers (2003).
} 
Greece, Korea, Malaysia, Philippines and Portugal) over the period 1977-1998 and estimating a Vector Autoregressive model (VAR), Caporale et al. (2004) obtained evidence of the relationship between stock market development (measured by capitalization to GDP and the value of listed shares to GDP) and economic development (measured by GDP in levels).

There is also a long list of empirical studies that focuses on the analysis of the relationship between the stock market and economic activity in specific countries. Some examples are: Hondroyiannis et al. (2005) in Greece; Adamopoulos (2010) in Germany; Ndako (2010) in South Africa; Ibrahim (2011) in Thailand; Marques et al. (2013) in Portugal; Pan and Mishra (2018) in China.

The empirical evidence of the relationship between the stock market and economic activity for the CEECs is not entirely clear, perhaps because of the short time horizons of these countries in a market economy system. For example, Caporale and Spagnolo (2012) examined the relationship between economic growth and the volatility of stock returns (stock index differences) in three CEEC countries (Czechia, Hungary and Poland) in a VAR-GARCH framework between 1996 and 2011. The results showed that there was a one-way causality from stock markets to economic growth, especially after joining the EU. Pece (2015) concluded that there was a two-way link between stock market performance (BET Index) and economic growth in Romania in the period 2000-2013. In contrast, by estimating a dynamic panel model, Caporale et al. (2015) suggested that stock market capitalization in the CEE-5 countries (Czechia, Hungary, Poland, Slovakia and Slovenia) had a small positive effect on economic growth; and for Baltic countries, Bulgaria and Romania's stock market capitalization had a positive but irrelevant effect. For 10 CIS (Commonwealth of Independent States) and 15 CEE countries, Cojocaru et al. (2016) concluded that the efficiency of the financial system and competitiveness were more significant than the amount of credits to the private sector provided by banks.

\section{$3 \quad$ Methodology and model specification}

\subsection{Data}

The variables used are stock market capitalization to GDP as a proxy for stock market development and real GDP (in chain-linked volumes) as a proxy for economic activity. Stock market capitalization is a measure commonly used to quantify stock market size (as in Ake and Ognaligui, 2010; Azam et al., 2016). Real GDP is a main objective for economic and political institutions and an objective in itself within the framework of economic policy, since the concept of GDP growth is often associated with a country's prosperity and well-being and is also used in virtually all empirical research as a fundamental variable in causal relationships.

The countries under study are Bulgaria, Czechia, Estonia, Hungary, Latvia, Lithuania, Poland, Romania, Slovakia and Slovenia. The stock market capitalization to GDP data for the countries have been obtained from the World Bank (Global Financial Development Database) except for Latvia, Lithuania and Romania, whose data come from the Federal Reserve Bank of St. Louis (FRED Economic Data), which declares the World Bank as its source. Real GDP data 
are obtained from Eurostat (Quarterly National Accounts Database). The variables are defined in Table 1. Table 2 specifies the frequency of the data in a range from 1995 to 2017, depending on the data available for each country from the sources consulted. A temporal disaggregation of low frequency (annual) to high frequency (quarterly) is performed for the stock market capitalization data through the method of Chow and Lin (1971), which finds the best linear unbiased estimator of the series used. The frequency of data for GDP is quarterly.

Table 1. Definition of variables

\begin{tabular}{|c|c|}
\hline Variable & Definition \\
\hline $\begin{array}{l}\text { CAP: } \\
\text { Stock market } \\
\text { capitalization to } \\
\text { GDP (\% of GDP) }\end{array}$ & $\begin{array}{l}\text { According to World Bank: "stock market capitalization is the value of listed shares } \\
\text { to GDP, calculated using the following deflation method: }\left\{(0.5) *\left[\mathrm{Ft} / \mathrm{P} \_ \text {et }+ \text { Ft- }\right.\right. \\
\text { 1/P_et-1]\}/[GDPt/P_at] where F is stock market capitalization, P_e is end-of } \\
\text { period CPI, and P_a is average annual CPI (end-of period CPI and average annual } \\
\text { CPI is calculated using the monthly CPI values)". }{ }^{2} \\
\text { Annual variable. It is transformed to quarterly by the method of Chow and Lin. }\end{array}$ \\
\hline $\begin{array}{l}\text { GDP: } \\
\text { Real GDP }\end{array}$ & $\begin{array}{l}\text { GDP measures the value of total final output of goods and services produced by an } \\
\text { economy within a certain period of time. } \\
\text { Chain-linked volumes, index } 2010=100 .^{3} \\
\text { According to Eurostat: "quarterly figures of Chain-linked level series (by annual } \\
\text { overlap method) are obtained by multiplying the ratio (previous year's price } \\
\text { quarterly figure at year T / average quarterly current price figure at year T-1) with } \\
\text { average quarterly chain-linked volume figure at year T-1".4 } \\
\text { Seasonally and calendar adjusted data except for Slovakia (seasonally adjusted } \\
\text { data, not calendar adjusted data). } \\
\text { Quarterly variable. }\end{array}$ \\
\hline
\end{tabular}

Table 2. Frequency of data

\begin{tabular}{llll}
\hline Country & $\begin{array}{l}\text { GDP } 2010=100 \\
\text { quarterly }\end{array}$ & CAP yearly & $\begin{array}{l}\text { Range after } \\
\text { transformations }\end{array}$ \\
\hline Bulgaria & $95: 1-17: 4$ & $93-12$ & $95: 1-12: 4$ \\
Czechia & $96: 1-17: 4$ & $93-12$ & $96: 1-12: 4$ \\
Estonia & $95: 1-17: 4$ & $98-12$ & $98: 4-12: 4$ \\
Hungary & $95: 1-17: 4$ & $92-17$ & $95: 1-17: 4$ \\
Latvia & $95: 1-17: 4$ & $96-12$ & $96: 4-12: 4$ \\
Lithuania & $95: 1-17: 4$ & $96-12$ & $96: 4-12: 4$ \\
Poland & $95: 1-17: 4$ & $92-17$ & $95: 1-17: 4$ \\
Romania & $95: 1-17: 4$ & $95-11$ & $95: 4-11: 4$ \\
Slovenia & $95: 1-17: 4$ & $95-17$ & $95: 4-17: 4$ \\
Slovakia & $95: 1-17: 4$ & $93-13$ & $95: 1-13: 4$ \\
\hline
\end{tabular}

\footnotetext{
2 https://datacatalog.worldbank.org/stock-market-capitalization-gdp

3 http://appsso.eurostat.ec.europa.eu/nui/show.do?dataset=namq_10_gdp\&lang=en

4 https://ec.europa.eu/eurostat/cache/metadata/EN/ei_qna_esms.htm
} 


\subsection{Methodology}

To analyze the causality relationship between financial and economic variables in the model, we use three different causality measures: Granger, Frequency Domain and Toda-Yamamoto. Specifically, we seek to find evidence of the relationship between stock market capitalization to GDP with real GDP in both directions and for each country. The results of these three measures will be used to demonstrate a causality relationship in a robust manner.

The first causality approach is Granger causality. According to Granger (1969), $X$ causes $Y$, if $X$ 's past values improve the estimate of $Y$, simply by using $Y^{\prime}$ s past values. It is therefore a concept that is based on predictability, that is, the ability of one variable to help predict another.

The null hypotheses in Granger causality tests are specified in each direction in the following form:

$$
\begin{aligned}
& \mathrm{H}_{\mathrm{a}}: \mathrm{GDP} \nrightarrow \mathrm{CAP} \\
& \text { Real GDP does not Granger cause stock market capitalization to GDP } \\
& \mathrm{H}_{\mathrm{b}}: \mathrm{CAP} \nrightarrow \mathrm{GDP} \\
& \text { Stock market capitalization to GDP does not Granger cause real GDP }
\end{aligned}
$$

The rejection of the null hypothesis leads to the verification of the existence of this relationship between the variables involved.

The model to be specified and estimated is a Vector Autoregressive model VAR, as in Nguyen and Pham (2014). In the application to the variables, the VAR model would have the following form, where the variables are endogenous:

$$
\begin{aligned}
& \mathrm{GDP}_{\mathrm{t}}=\mu_{0}+\sum_{\mathrm{i}=1}^{\mathrm{n}} \alpha_{\mathrm{i}} \mathrm{GDP}_{\mathrm{t}-\mathrm{i}}+\sum_{\mathrm{i}=1}^{\mathrm{n}} \beta_{\mathrm{i}} \mathrm{CAP}_{\mathrm{t}-\mathrm{i}}+\varepsilon_{1 \mathrm{t}}(1) \\
& \mathrm{CAP}_{\mathrm{t}}=\gamma_{0}+\sum_{\mathrm{i}=1}^{\mathrm{n}} \lambda_{\mathrm{i}} \mathrm{CAP}_{\mathrm{t}-\mathrm{i}}+\sum_{\mathrm{i}=1}^{\mathrm{n}} \delta_{\mathrm{i}} \mathrm{GDP}_{\mathrm{t}-\mathrm{i}}+\varepsilon_{2 \mathrm{t}}(2)
\end{aligned}
$$

The second causality measure is the Frequency Domain approach. A spectral causality test is proposed (Breitung and Candelon, 2006), whereby causality relationships are broken down into the frequency spectrum that can be attributed to causality relationships in the short, medium and long-terms. Therefore, this approach provides the temporal vision of causality. Tiwari et al. (2015) specifically used this methodology in India. Croux and Reusens (2013) found for the G-7 countries between 1991 and 2010 that slowly fluctuating components of the stock prices (components with a periodicity larger or equal to one year) contained predictive power for future GDP, whereas quickly fluctuating components did not.

As Gomez-Gonzalez et al. (2015) indicated, the spectral function of each variable is estimated, cycles are extracted by Fourier analysis and the co-movement between cycles is estimated by using the cross-spectral density function and its related measures of coherence. Breitung and Candelon (2006) explained:

Let $Z_{t}=\left[x_{t}, y_{t}\right]^{\prime}$ be a two-dimensional vector of time series observed as $t=1,2 \ldots T, Z_{t}$ represents a finite-order VAR of the following type: 


$$
\Theta(\mathrm{L}) \mathrm{Z}_{\mathrm{t}}=\varepsilon_{\mathrm{t}}(3)
$$

Where $\Theta(\mathrm{L})=\mathrm{I}-\Theta_{1} \mathrm{~L}-\cdots-\Theta_{\mathrm{p}} \mathrm{L}_{\mathrm{p}}$ is a $2 \times 2$ lag polynomial with $\mathrm{L}^{\mathrm{k}} \mathrm{Z}_{\mathrm{t}}=\mathrm{Z}_{\mathrm{t}-\mathrm{k}}$. The error vector $\varepsilon_{\mathrm{t}}$ is white noise with $\mathrm{E}\left(\varepsilon_{\mathrm{t}}\right)=0$ and $\mathrm{E}\left(\varepsilon_{\mathrm{t}} \varepsilon_{\mathrm{t}}{ }^{\prime}\right)=\Sigma$, where $\Sigma$ is positive definite. Let $\mathrm{G}$ be the lower triangular matrix of the Cholesky decomposition $G^{\prime} G=\Sigma^{-1}$. The moving average representation of the system (which is assumed to be stationary) is:

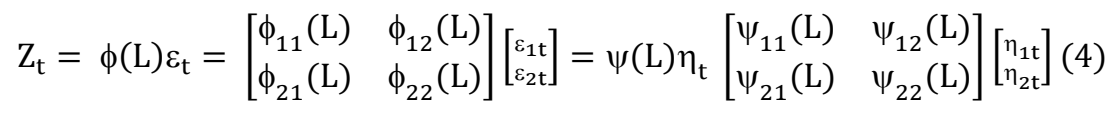

Where $\phi(\mathrm{L})=\Theta(\mathrm{L})^{-1}$ and $\psi(\mathrm{L})=\phi(\mathrm{L}) \mathrm{G}^{-1}$. The spectral density of $\mathrm{x}_{\mathrm{t}}$ can be expressed as:

$$
\mathrm{f}_{\mathrm{x}}(\omega)=\frac{1}{2 \Pi}\left\{\left|\psi_{11}\left(\mathrm{e}^{-\mathrm{i} \omega}\right)\right|^{2}+\left|\psi_{12}\left(\mathrm{e}^{-\mathrm{i} \omega}\right)\right|^{2}\right\}(5)
$$

Causality is defined as (Geweke, 1982; Hosoya, 1991):

$$
\mathrm{M}_{\mathrm{y} \rightarrow \mathrm{x}}(\omega)=\log \left[1+\frac{\left|\psi_{12}\left(\mathrm{e}^{-\mathrm{i} \omega}\right)\right|^{2}}{\left|\psi_{11}\left(\mathrm{e}^{-\mathrm{i} \omega}\right)^{2}\right|}\right](6)
$$

If $\left|\psi_{12}\left(\mathrm{e}^{-\mathrm{i} \omega}\right)\right|^{2}=0$ means that $y$ does not cause an $x$ at frequency ( $\left.\omega\right)$. Therefore, to test that $y$ does not cause $x$ at frequency $(\omega)$, within a bivariate framework, the null hypothesis is:

$$
\mathrm{H}_{0}: \mathrm{M}_{\mathrm{y} \rightarrow \mathrm{x}}(\omega)=0(7)
$$

The complete frequency range is from zero to $\Pi$. The frequency $(\omega)$ is equal to $2 \Pi /$ cycle duration (T); therefore, values of $(\omega)$ near $\Pi$ correspond to short-term, whereas values of $(\omega)$ near zero correspond to long-term (Gomez-Gonzalez et al., 2015).

And finally, we analyze the Toda-Yamamoto approach (Toda and Yamamoto, 1995). These authors step forward with the Granger causality approach and use the modified Wald test (MWALD), based on a VAR( $\left.\mathrm{k}+\mathrm{d}_{\max }\right)$ model where $\mathrm{k}$ is the optimal order of system lags, and $\mathrm{d}_{\max }$ is the maximum order of model integration (Saafi et al., 2016). This approach includes additional lags to consider the non-stationarity of the series, and the number of additional lags is based on the order of integration of the series. The VAR can be used in non-stationary series (Andersson et al., 2016). Saafi et al. (2016) used this approach to analyze causality between financial integration and economic growth for a group of 19 developing and developed countries. Andersson et al. (2016) analyzed causality between the banking sector and Chinese economic growth with the Toda-Yamamoto approach. Caporale et al. (2004) also used this approach when studying the relationship between stock market development and economic growth for Argentina, Chile, Greece, Korea, Malaysia, Philippines and Portugal during the period 1977-1998 and estimating a Vector Autoregressive model (VAR).

In the application to the variables and in accordance with the approach of Toda and Yamamoto, the VAR model would have the following form: 


$$
\begin{aligned}
& \mathrm{GDP}_{\mathrm{t}}=\mu_{0}+\sum_{\mathrm{i}=1}^{\mathrm{k}} \alpha_{1 \mathrm{i}} \mathrm{GDP}_{\mathrm{t}-\mathrm{i}}+\sum_{\mathrm{j}=\mathrm{k}+1}^{\mathrm{k}+\mathrm{d}_{\max }} \alpha_{2 \mathrm{j}} \mathrm{GDP}_{\mathrm{t}-\mathrm{j}}+\sum_{\mathrm{i}=1}^{\mathrm{k}} \beta_{1 \mathrm{i}} \mathrm{CAP}_{\mathrm{t}-\mathrm{i}}+\sum_{\mathrm{j}=\mathrm{k}+1}^{\mathrm{k}+\mathrm{d}_{\max }} \beta_{2 \mathrm{j}} \mathrm{CAP}_{\mathrm{t}-\mathrm{j}}+\varepsilon_{2 \mathrm{t}}(8) \\
& \mathrm{CAP}_{\mathrm{t}}=\gamma_{0}+\sum_{\mathrm{i}=1}^{\mathrm{k}} \lambda_{1 \mathrm{i}} \mathrm{CAP}_{\mathrm{t}-\mathrm{i}}+\sum_{\mathrm{j}=\mathrm{k}+1}^{\mathrm{k}+\mathrm{d}_{\max }} \lambda_{2 \mathrm{j}} \mathrm{CAP}_{\mathrm{t}-\mathrm{j}}+\sum_{\mathrm{i}=1}^{\mathrm{k}} \delta_{1 \mathrm{i}} \mathrm{GDP}_{\mathrm{t}-\mathrm{i}}+\sum_{\mathrm{j}=\mathrm{k}+1}^{\mathrm{k}+\mathrm{d}_{\max }} \delta_{2 \mathrm{j}} \mathrm{GDP}_{\mathrm{t}-\mathrm{j}}+\varepsilon_{1 \mathrm{t}}(9)
\end{aligned}
$$

\section{$4 \quad$ Empirical analysis and results}

The first step for empirical study involves testing for unit root in time series. The series should not have a unit root for both Granger causality, i.e., they should be $\mathrm{I}(0)$ or stationary, whereas in the Toda-Yamamoto approach and Frequency Domain causality (if the series cointegrate), it is not a necessary condition.

First, we transform the time series into logarithms due to its exponential behavior. Then, the presence of unit roots is analyzed by means of the Phillips-Perron test (Phillips and Perron, 1988) whereby the null hypothesis is the existence of a unit root, or I(1). The results indicate (see Annex 2) that LCAP and LGDP are I(1) in all countries. For Poland and Hungary, the stationarity of LCAP is also tested with the KPSS test (Kwiatkowski et al., 1992). For these countries, LCAP does not have a linear trend, so the results could be confusing when applying a trend. The graph shows for these countries that LCAP could be I(1). The KPSS test results show that LCAP is not stationary, which is why another test is used. Consequently, the series are differentiated to correct the presence of a unit root, as well as in first differences to verify that the order of integration is 1.

Secondly, the presence of cointegration is studied between LCAP and LGDP (see results in Annex 3). Cointegration indicates the existence of long-term relationships between the different variables of the model. Cointegration exists when given two (or more) non-stationary series (they must be $\mathrm{I}(\mathrm{d})$ of order $\mathrm{d}$ in the variables), there is a linear combination between them that is stationary. The Johansen method has been used to verify cointegration between the nonstationary series LCAP and LGDP at levels (Johansen; 1991, 1995). The results show the evidence of a cointegration vector $(1,-1)$ between the two variables for Bulgaria, Hungary, Latvia, Romania, Slovakia and Slovenia, whereas it does not exist in Czechia, Estonia, Lithuania and Poland.

The third step, once the stationarity and cointegration of the series have been analyzed, is studying causality from the different approaches.

For Granger causality, the models established in equations (1) and (2) are estimated with an unrestricted VAR if the series do not cointegrate. If they cointegrate, it is estimated with an Error Correction Model (ECM). We have to take into account that if the series cointegrate the variables are used at levels (LCAP and LGDP) and if they do not cointegrate, LCAP and LGDP 
are used in first differences. ${ }^{5}$ Once the model has been estimated, the Granger causality test is carried out from them. Granger causality is sensitive to the number of lags included, and they have been selected by using Akaike Information Criteria (AIC) and Schwarz Information Criteria (SC). The selected VAR models are summarized in Table 3. For Granger causality, the optimum lag is obtained with the series in differences, and for the Toda-Yamamoto approach, it is not necessary.

Granger causality results are shown in Table 4. The results reveal Granger causality from LGDP (real GDP) to LCAP (stock market capitalization to GDP) in Bulgaria, Estonia and Slovenia. In the opposite direction, the results reveal Granger causality from LCAP to LGDP in six countries: Bulgaria, Czechia, Latvia, Lithuania, Poland and Slovakia.

The causality from the Frequency Domain approach ${ }^{6}$ is represented in Table 5, where the countries shown are those where the angular frequency $(\omega)$ is significant (at a significance level of 5\%) and the corresponding time range (Poland is not shown because of the angular frequency $(\omega)$ is not significant). Annex 4 shows the results in graphical form, where in the abscissa axis the frequency $(\omega)$ is represented, which is equal to $2 \Pi /$ cycle duration $(T)$. The probability is shown on the ordinate axis. Transforming the previous function with respect to time would remain:

$$
\text { Cycle duration }(\mathrm{T})=\frac{2 \Pi}{\omega}(10)
$$

For the interpretation of results, short-term is considered less than two years; medium-term between two and five years; and long-term five years or more.

For the causal relationship of LGDP to LCAP, the evidence is in the long-term for Bulgaria, Hungary, Lithuania, Romania and Slovenia, and in the medium and long-term for Estonia. For the causal relationship of LCAP to LGDP, the evidence is in the long-term for Czechia, Hungary, Latvia, Lithuania and Romania, and in the medium and long-term for Bulgaria, Slovakia and Slovenia. Comparing with Granger causality, these results are similar in Bulgaria (LGDP to LCAP, and LCAP to LGDP); Estonia and Slovenia (LGDP to LCAP); and Czechia, Latvia, Lithuania and Slovakia (LCAP to LGDP).

Table 3. Optimum VAR lag

\begin{tabular}{llllll}
\hline Country & $\begin{array}{l}\text { For Granger } \\
\text { causality }\end{array}$ & $\begin{array}{l}\text { For Toda- } \\
\text { Yamamoto } \\
\text { approach }\end{array}$ & Country & $\begin{array}{l}\text { For Granger } \\
\text { causality }\end{array}$ & $\begin{array}{l}\text { For Toda- } \\
\text { Yamamoto } \\
\text { approach }\end{array}$ \\
\hline Bulgaria & 6 & 6 & Lithuania & 1 & 2 \\
Czechia & 5 & 6 & Poland & 1 & 2 \\
Estonia & 5 & 5 & Romania & 2 & 2 \\
Hungary & 2 & 2 & Slovakia & 2 & 2 \\
Latvia & 3 & 3 & Slovenia & 2 & 2 \\
\hline
\end{tabular}

\footnotetext{
5 First differences of log-level variables are equivalent to their growth rates. Therefore, instead of calling them by their original names, it is appropriate to refer to them in terms of economic growth and the variations of the stock market capitalization to GDP ratio.

6 If the series do not cointegrate, LCAP and LGDP are used in first differences. If the series cointegrate, LCAP and LGDP are used at levels.
} 
Table 4. Granger Causality Test

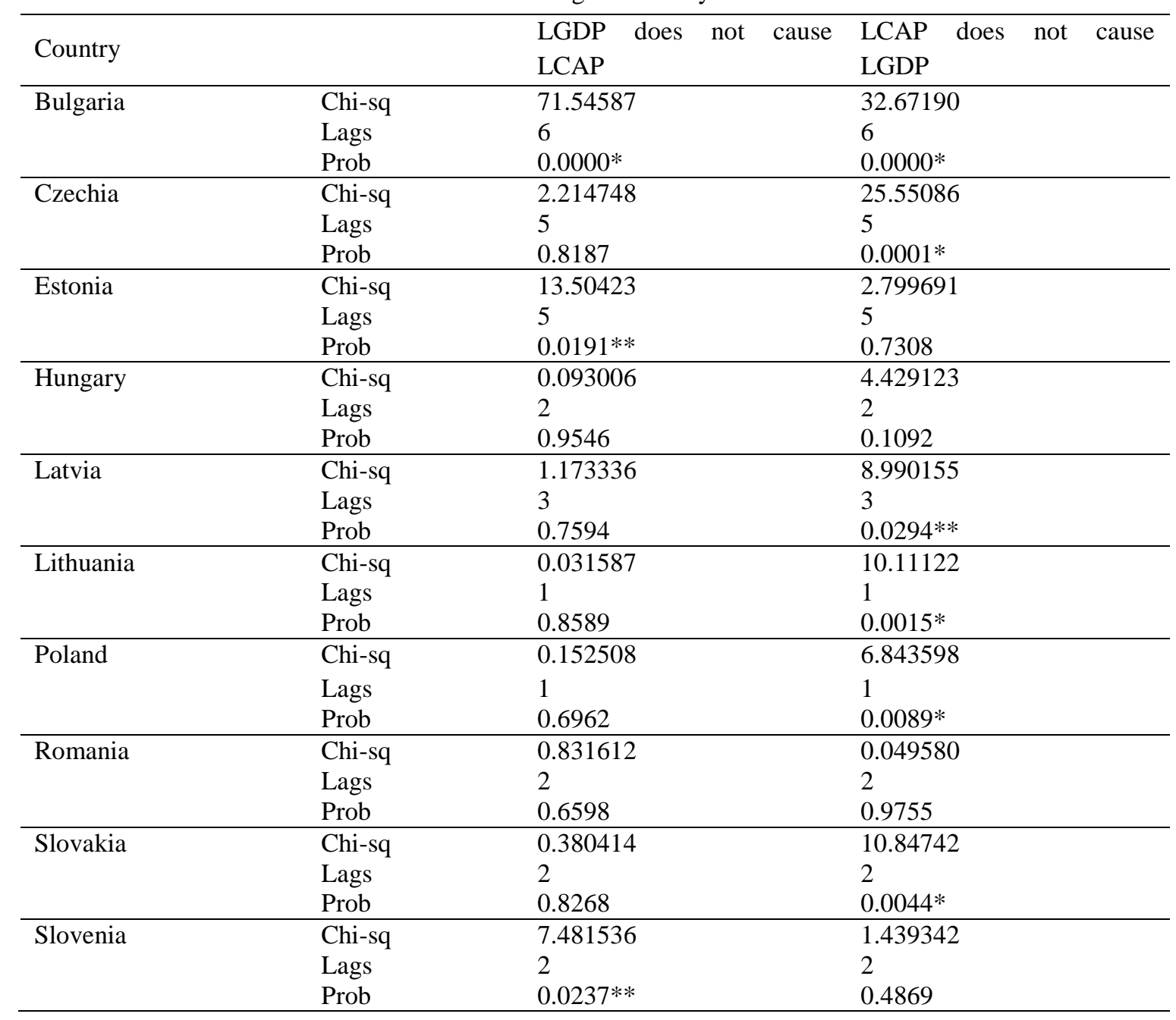

Notes: *,**,*** show that the null hypothesis is rejected with a significance level of $1 \%, 5 \%, 10 \%$ respectively. For Czechia, Estonia, Lithuania and Poland, LCAP and LGDP are used in first differences (they do not cointegrate). For Bulgaria, Hungary, Latvia, Romania, Slovakia and Slovenia, LCAP and LGDP are used at levels (they cointegrate).

For causality from the Toda-Yamamoto approach, we estimate the VAR models established in equations (8) and (9), and causality tests are performed from them. We employ Akaike Information Criteria (AIC) and Schwarz Information Criteria (SC) to find the optimal number of lags, shown in Table 3.

The results of causality from the Toda-Yamamoto approach ${ }^{7}$ are shown in Table 6. The results reveal causality from LGDP to LCAP in Bulgaria, Estonia and Slovenia. In the opposite direction, LCAP to LGDP in five countries: Bulgaria, Czechia, Lithuania, Poland and Slovakia.

\footnotetext{
${ }^{7}$ LCAP and LGDP are used at levels, since stationarity and cointegration are not relevant.
} 
Table 5. Causality from the Frequency Domain approach

\begin{tabular}{lllll}
\hline & \multicolumn{2}{l}{ LGDP does not cause LCAP } & \multicolumn{2}{l}{ LCAP does not cause LGDP } \\
\hline \multirow{2}{*}{ Country } & $\begin{array}{l}\text { Angular } \\
\text { frequency }(\omega)\end{array}$ & $\begin{array}{l}\text { Time range } \\
\text { (years) }\end{array}$ & $\begin{array}{l}\text { Angular } \\
\text { frequency }(\omega)\end{array}$ & $\begin{array}{l}\text { Time range } \\
\text { (years) }\end{array}$ \\
\hline Bulgaria & 0.0816 to 0.3264 & $76.9998-19.2500$ & 0.0816 to 0.2448 & $76.9998-25.6667$ \\
& 0.5712 to 1.1424 & $11.0000-5.5000$ & 0.4896 to 0.7344 & $12.8333-8.5556$ \\
& & & 1.1424 to 1.4688 & $5.5000-4.2778$ \\
& & & 1.7952 to 1.8768 & $3.5000-3.3478$ \\
& & & 2.2848 to 2.4480 & $2.7500-2.5667$ \\
& & & 2.8560 to 3.0192 & $2.2000-2.0811$ \\
\hline Czechia & & $11.2000-2.9474$ & 0.6614 to 0.9094 & $9.4998-6.9092$ \\
\hline Estonia & 0.5610 to 2.1318 & 2.0741 & & \\
& 3.0294 & $46.0000-9.2000$ & 0.1366 to 0.8878 & $46.0000-7.0769$ \\
\hline Hungary & 0.1366 to 0.6830 & & 0.0967 to 0.3867 & $65.0003-16.2500$ \\
\hline Latvia & & $8.0000-6.4000$ & 0.0982 & 63.9999 \\
\hline Lithuania & 0.7854 to 0.9817 & 65.0003 & 0.0966 to 0.2899 & $65.0003-21.6667$ \\
\hline Romania & 0.0966 & & 0.0776 to 0.6206 & $81.0002-10.1250$ \\
\hline Slovakia & & 1.9393 to 3.0252 & $3.2400-2.0769$ \\
\hline Slovenia & 0.0706 & 88.9995 & 0.4236 to 1.4825 & $14.8333-4.2381$ \\
& 0.5648 to 0.9178 & $11.1250-6.8462$ & 2.8945 to 3.0357 & $2.1707-2.0698$ \\
\hline
\end{tabular}

Notes: For Czechia, Estonia and Lithuania LCAP and LGDP are used in first differences (they do not cointegrate). For Bulgaria, Hungary, Latvia, Romania, Slovakia and Slovenia, LCAP and LGDP are used at levels (they cointegrate).

According to the results, there is evidence of bi-directional causality in all three approaches and in both directions in a considerable number of countries (Table 7). There is empirical evidence of causality in all the countries that joined the European Union in 2004 and 2007. In the three most developed countries, the results point to the existence of causal relationships from stock market capitalization to real GDP in this way: in Czechia from Granger causality, the Toda-Yamamoto approach and the Frequency Domain approach; in Hungary from the Frequency Domain approach; in Poland from Granger causality and Toda-Yamamoto approach.

Also noteworthy are the cases of Estonia, Lithuania and Latvia, which are countries with a common pattern (they comprise the Baltic Republics). In Lithuania and Latvia, Granger causality is from LCAP to LGDP, whereas in Estonia, Granger causality is from LGDP to LCAP. For these countries, causality from the Toda-Yamamoto approach exists from LCAP to LGDP in Lithuania and from LGDP to LCAP in Estonia. Causality from the Frequency Domain approach exists from LCAP to LGDP in Latvia and Lithuania and from LGDP to LCAP in Estonia and Lithuania.

In Bulgaria, causality exists in all directions and approaches, whereas in Romania, causality exists from the Frequency Domain approach. 
Table 6. Causality from the Toda-Yamamoto approach

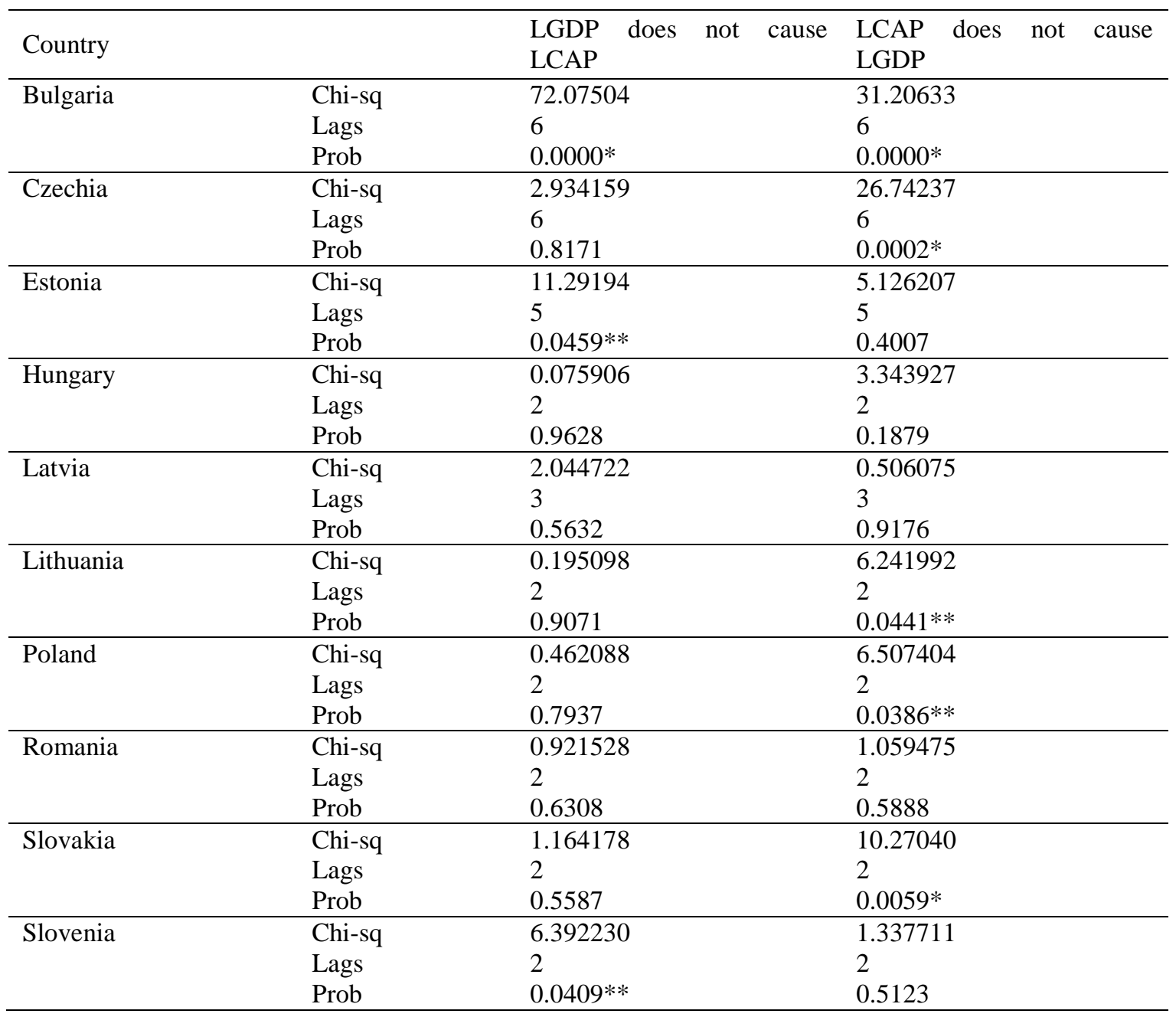

Notes: *, **,** show that the null hypothesis is rejected with a significance level of $1 \%, 5 \%$ and $10 \%$ respectively. LCAP and LGDP are used at levels for all the countries.

Especially in those countries where there is cointegration, i.e., a long-term relationship between the variables -Bulgaria, Hungary, Latvia, Romania, Slovakia and Slovenia-, the causality analysis from the Frequency Domain approach shows the significance in a time horizon (medium- and long-term). This long-term equilibrium relationship should be exploited in terms of the contribution of the stock market capitalization to GDP to real GDP particularly in those countries with less developed markets - Bulgaria, Latvia, Romania, Slovakia and Slovenia. 
Table 7. Summary of results

\begin{tabular}{|c|c|c|c|c|c|}
\hline Country & & Granger & Toda- Yamamoto & Frequency Domain & Cointegration \\
\hline \multirow[t]{2}{*}{ Bulgaria } & LCAP to LGDP & $*$ & $*$ & Medium and long-term & $*$ \\
\hline & LGDP to LCAP & $*$ & $*$ & Long-term & \\
\hline \multirow[t]{2}{*}{ Czechia } & LCAP to LGDP & * & $*$ & Long-term & \\
\hline & LGDP to LCAP & & & & \\
\hline \multirow[t]{2}{*}{ Estonia } & LCAP to LGDP & & & & \\
\hline & LGDP to LCAP & $*$ & $*$ & Medium and long-term & \\
\hline \multirow[t]{2}{*}{ Hungary } & LCAP to LGDP & & & Long-term & $*$ \\
\hline & LGDP to LCAP & & & Long-term & \\
\hline \multirow{2}{*}{ Latvia } & LCAP to LGDP & $*$ & & Long-term & $*$ \\
\hline & LGDP to LCAP & & & & \\
\hline \multirow[t]{2}{*}{ Lithuania } & LCAP to LGDP & $*$ & $*$ & Long-term & \\
\hline & LGDP to LCAP & & & Long-term & \\
\hline \multirow[t]{2}{*}{ Poland } & LCAP to LGDP & $*$ & $*$ & & \\
\hline & LGDP to LCAP & & & & \\
\hline \multirow[t]{2}{*}{ Romania } & LCAP to LGDP & & & Long-term & $*$ \\
\hline & LGDP to LCAP & & & Long-term & \\
\hline \multirow[t]{2}{*}{ Slovakia } & LCAP to LGDP & $*$ & $*$ & Medium and long-term & $*$ \\
\hline & LGDP to LCAP & & & & \\
\hline \multirow[t]{2}{*}{ Slovenia } & LCAP to LGDP & & & Medium and long-term & $*$ \\
\hline & LGDP to LCAP & $*$ & $*$ & Long-term & \\
\hline
\end{tabular}

Therefore, the importance of stock market size in the early stages of the transition for these emerging countries (CEECs) and how stock market development could catalyze economic development should be considered by the policy makers after proving that there is a link between stock market capitalization and GDP, which is also in accordance with Caporale and Spagnolo (2012).

Consequently, measures should be taken to promote the better functioning of these stock markets, given their importance. For example, Draženović and Kusanović (2016) emphasized the importance of continuing with investment liberalization for institutional investors and implementing measures for stimulation of savings and investments, thus strengthening property rights, among others. The authors showed in a sample of six CEE countries (Croatia, Czechia, Hungary, Poland, Slovakia and Slovenia), over the period 1995-2010, that saving is a good predictor of stock market development (measured as stock market capitalization to GDP) as a high level of macroeconomic stability (lower inflation rate), as well as the complementary development of capital markets and banks.

In relation to the functioning of the market as well, the quality of information and the strength of legal system are essential to the financial development, in the same sense as the financial development for economic growth (Claessens et al., 2000). With respect to the quality of information in terms of efficiency, ${ }^{8}$ there is a margin for improvement in these economies as the following authors have shown. By testing the martingale hypothesis (from 2000-2009),

\footnotetext{
8 "In weak-form efficient markets, current prices are the best predictors of the next period's prices. Since historical information is already embedded in current prices, past prices have no role in predicting future prices” (Smith, 2012, p. 689).
} 
Smith (2012) demonstrated that Hungarian and Polish markets are among the most efficient markets, and Estonia is among the least. Dragotă and Ţilică (2014) showed that for stocks of 20 East European formerly communist countries, there were severe doubts concerning stock market efficiency for these countries in the analyzed period (January 2008-December 2010). Therefore, due to the evidence, the efficiency of the markets should be improved.

\section{Conclusions}

The aim of this paper was to study the link between stock market capitalization to GDP and real GDP in ten Central and Eastern European countries (CEECs) which joined the European Union in 2004 (Czechia, Estonia, Hungary, Latvia, Lithuania, Poland, Slovakia and Slovenia) and 2007 (Bulgaria and Romania) in the framework of a cointegrated VAR. We investigate this relationship through the study of three different approaches to causality: Granger, Frequency Domain and Toda-Yamamoto.

These former communist economies developed important transition processes to become market economies. Therefore, we analyzed the direction of causality and we tried to find out whether stock markets could be catalysts for real GDP in these countries. We studied empirically whether stock market capitalization to GDP caused real GDP and vice versa. The results from the different causality approaches show support for the relationship between stock market capitalization to GDP and real GDP, with a two-way causality link. This stronger relationship exists in those countries where we found evidence of a long-term relationship (cointegration): Bulgaria, Hungary, Latvia, Romania, Slovakia and Slovenia.

Therefore, the potential contribution of stock market development to economic activity must be taken into consideration in these countries. In this context, policy makers should encourage stock market development as a potential way to increase economic growth where there is a transfer of resources from the financial to the productive sector; policy makers should also undertake legal reforms to increase transparency and efficiency and to ensure better performance in these markets. In this context, the Federation of European Securities Exchanges (2014) proposed an Action Plan for European Capital Markets. It suggested "more financing through capital markets helps achieve not just greater amounts of financing but also higher levels of innovation, risk management, savings mobilisation, wealth distribution and job creation" (Federation of European Securities Exchanges, 2014, p.3). The Action Plan for European Capital Markets, "well implemented and driven by policy makers and regulators together with stock markets, it would reduce the cost of financing and to be able to provide more capital and profitability to all companies especially those most affected by the crisis: SMEs” (Bolsas y Mercados Españoles, 2014, p.33). 


\section{References}

Adamopoulos, A. (2010). Stock market and economic growth: An empirical analysis for Germany. Business and Economics Journal, 2010, BEJ-1. http://journaldatabase.info/articles/stock_market_economic_growth_empirical.htm

Ake, B. and Ognaligui, R. W. (2010). Financial stock market and economic growth in developing countries: The case of Duala Stock Exchange in Cameroon. International Journal of Business and Management, 5(5), 82-88. http://dx.doi.org/10.5539/ijbm.v5n5p82

Andersson, F. N. G., Burzynska, K. and Opper, S. (2016). Lending for growth? A Granger causality analysis of China's finance-growth nexus. Empirical Economics, 51(3), 897-920. https://doi.org/10.1007/s00181-015-1034-8

Azam, M., Haseeb, M., Samsi, A. B. and Raji, J. O. (2016). Stock market development and economic growth: Evidences from Asia-4 countries. International Journal of Economics and Financial Issues, 6(3), 1200-1208.

Bolsas y Mercados Españoles (2014). Las Bolsas comprometidas con la financiación, el crecimiento y el empleo. Available at: https://www.bolsasymercados.es/esp/Estudios-

Publicaciones/Documento/5093_Las_Bolsas_comprometidas_con_la_financiaci\%C3\%B3n_el_cr ecimiento_y_el_empleo

Bonin, J. and Wachtel, P. (2003). Financial sector development in transition economies: Lessons from the first decade. Financial Markets, Institutions \& Instruments, 12(1), 1-66. http://dx.doi.org/10.1111/1468-0416.t01-1-00001

Breitung, J. and Candelon, B. (2006). Testing for short- and long-run causality: A frequency-domain approach. Journal of Econometrics, 132(2), 363-378. http://dx.doi.org/10.1016/j.jeconom.2005.02.004

Caporale, G. M., Rault, C., Sova, A. D. and Sova, R. (2015). Financial development and economic growth: Evidence from 10 new European Union members. International Journal of Finance \& Economics, 20(1), 48-60. http://dx.doi.org/10.1002/ijfe.1498

Caporale, G. M., Howells, P. G. and Soliman, A. M. (2004). Stock market development and economic growth: The causal linkage. Journal of Economic Development, 29(1), 33-50. http://www.jed.or.kr/full-text/29-1/02_J665_.PDF

Caporale, G. M. and Spagnolo, N. (2012). Stock market, economic growth and EU accession: Evidence from three CEECs. International Journal of Monetary Economics and Finance, 5(2), 183-191. http://dx.doi.org/10.1504/IJMEF.2012.048736

Chow, G. C. and Lin, A. (1971). Best linear unbiased interpolation, distribution, and extrapolation of time series by related series. The Review of Economics and Statistics, 53(4), 372-375. http://dx.doi.org/10.2307/1928739

Claessens, S., Djankov, S. and Klingebiel, D. (2000). Stock markets in transition economies. Financial Sector Discussion Paper No. 5. Available at SSRN: https://ssrn.com/abstract=240703 or http://dx.doi.org/10.2139/ssrn.240703 
Cojocaru, L., Falaris, E. M., Hoffman, S. D. and Miller, J. B. (2016). Financial system development and economic growth in transition economies: New empirical evidence from the CEE and CIS countries. Emerging Markets Finance and Trade, 52(1), 223-236.

http://dx.doi.org/10.1080/1540496X.2015.1013828

Croux, C. and Reusens, P. (2013). Do stock prices contain predictive power for the future economic activity? A Granger causality analysis in the frequency domain. Journal of Macroeconomics, 35(1), 93-103. https://doi.org/10.1016/j.jmacro.2012.10.001

Demirgüç-Kunt, A. and Levine, R. (2001). Bank-based and market-based financial systems: Crosscountry comparisons. In A. Demirgüç-Kunt and R. Levine (Eds.), Financial structure and economic growth: A cross-country comparison of banks, markets, and development (pp. 81-140), Cambridge, MA: MIT Press.

Dragotă, V. and Ţilică, E. V. (2014). Market efficiency of the Post Communist East European stock markets. Central European Journal of Operations Research, 22, 307-337. https://doi.org/10.1007/s10100-013-0315-6

Draženović, B. O. and Kusanović, T. (2016). Determinants of capital market in the new member EU countries. Economic Research-Ekonomska Istraživanja, 29(1), 758-769. http://dx.doi.org/10.1080/1331677X.2016.1197551

Federation of European Securities Exchanges (2014). A blueprint for European capital markets: how to unleash markets' potential to finance dynamic and sustainable growth. Available at: https://fese.eu/blog/blueprint-for-european-capital-markets/

Gemech, F. and Struthers, J. (2003). The Mckinnon-Shaw hypothesis: Thirty years on: A review of recent developments in financial liberalization theory. In Annual Conference on Globalisation and Development, Glasgow, Scotland: Development Studies Association (DSA).

Geweke, J. (1982). Measurement of linear dependence and feedback between multiple time series. Journal of the American Statistical Association, 77(378), 304-313. http://dx.doi.org/10.1080/01621459.1982.10477803

Goldsmith, R. W. (1969). Financial structure and development. New Haven, CT: Yale University Press.

Gomez-Gonzalez, J. E., Villamizar-Villegas, M., Zarate, H. M., Amador, J. S. and Gaitan-Maldonado, C. (2015). Credit and business cycles: Causal effects in the frequency domain. Ensayos sobre Política Económica, 33(78), 176-189. https://doi.org/10.1016/j.espe.2015.05.002

Granger, C. W. J. (1969). Investigating causal relations by econometric models and cross-spectral methods. Econometrica, 37(3), 424-438. http://dx.doi.org/10.2307/1912791

Hondroyiannis, G., Lolos, S. and Papapetrou, E. (2005). Financial markets and economic growth in Greece, 1986-1999. Journal of International Financial Markets, Institutions and Money, 15(2), 173-188. http://dx.doi.org/10.1016/j.intfin.2004.03.006

Hosoya, Y. (1991). The decomposition and measurement of the interdependence between second-order stationary processes. Probability Theory and Related Fields, 88(4), 429-44. https://doi.org/10.1007/BF01192551

Ibrahim, M. H. (2011). Stock market development and macroeconomic performance in Thailand. Engineering Economics, 22(3), 230-240. http://dx.doi.org/10.5755/j01.ee.22.3.513 
Iorgova, S. and Ong, L. L. (2008). The capital markets of emerging Europe: Institutions, instruments and investors. IMF Working Paper 08/103. Available at: https://www.imf.org/ /media/Websites/IMF/imported-full-textpdf/external/pubs/ft/wp/2008/_wp08103.ashx.

Johansen, S. (1991). Estimation and hypothesis testing of cointegration vectors in Gaussian Vector Autoregressive models. Econometrica, 59(6), 1551-1580. http://dx.doi.org/10.2307/2938278

Johansen, S. (1995). Likelihood-based inference in cointegrated Vector Autoregressive models. Oxford: Oxford University Press. http://dx.doi.org/10.1093/0198774508.001.0001

King, R. G. and Levine, R. (1993). Finance and growth: Schumpeter might be right. The Quarterly Journal of Economics, 108(3), 717-737. http://dx.doi.org/10.2307/2118406

Köke, J. and Schröder, M. (2003). The prospects of capital markets in Central and Eastern Europe. Eastern European Economics, 41(4), 5-37. https://doi.org/10.1080/00128775.2003.11041052

Kwiatkowski, D., Phillips, P. C. B., Schmidt, P. and Shin, Y. (1992). Testing the null hypothesis of stationarity against the alternative of a unit root: How sure are we that economic time series have a unit root? Journal of Econometrics, 54(1-3), 159-178. https://doi.org/10.1016/03044076(92)90104-Y

Levine, R. (1997). Financial development and economic growth: Views and agenda. Journal of Economic Literature, 35(2), 688-726. https://www.jstor.org/stable/2729790

Levine, R. (2002). Bank-based or Market-based financial systems: Which is better? Journal of Financial Intermediation, 11(4), 398-428. http://dx.doi.org/10.1006/jfin.2002.0341

Levine, R. (2005). Finance and growth: Theory and evidence. In P. Aghion and S. N. Durlauf (Eds.), Handbook of Economic Growth (pp. 865-934), Amsterdam: Elsevier.

Levine, R. and Zervos, S. (1996). Stock market development and long-run growth. World Bank Economic Review, 10(2), 323-339. http://dx.doi.org/10.1596/1813-9450-1582

Levine, R. and Zervos, S. (1998). Stock markets, banks and economic growth. The American Economic Review, 88(3), 537-558. https://www.jstor.org/stable/116848

McKinnon, R. I. (1973). Money and capital in economic development. Washington, D.C.: The Brookings Institution.

MacKinnon, J. G. (1996). Numerical distribution functions for unit root and cointegration test. Journal of Applied Econometrics, 11(6), 601-618. https://doi.org/10.1002/(SICI)1099-1255(199611)11:6\%3C601::AID-JAE417\%3E3.0.CO;2-T

MacKinnon, J. G., Haug, A. A. and Michelis, L. (1999). Numerical distribution functions of likelihood ratio tests for cointegration. Journal of Applied Econometrics, 14(5), 563-77. https://doi.org/10.1002/(SICI)1099-1255(199909/10)14:5\%3C563::AID-JAE530\%3E3.0.CO;2-R

Marques, L. M., Fuinhas, J. A. and Marques, A. C. (2013). Does the stock market cause economic growth? Portuguese evidence of economic regime change. Economic Modelling, 32, 316-324. http://dx.doi.org/10.1016/j.econmod.2013.02.015

Mauro, P. (2003). Stock returns and output growth in emerging and advanced economies. Journal of Development Economics, 71(1), 129-153. http://dx.doi.org/10.1016/S0304-3878(02)00136-0 
Ndako, U. B. (2010). Stock markets, banks and economic growth: Time series evidence from South Africa. The African Finance Journal, 12(2), 72-92.

Nguyen, H. T. and Pham, H. (2014). Relationship between stock market development and economic growth: Evidences from Canada and Australia. International Journal of Economics and Finance, 6(7), 1-10. http://dx.doi.org/10.5539/ijef.v6n7p1

Pajuste, A. (2002). Corporate governance and stock market performance in Central and Eastern Europe: A study of nine countries, 1994-2001. UCL SSEES Economics and Business working paper series 22. Available at SSRN: https://ssrn.com/abstract=310419 or http://dx.doi.org/10.2139/ssrn.310419

Pan, L. and Mishra, V. (2018). Stock market development and economic growth: Empirical evidence from China. Economic Modelling, 68, 661-673. http://dx.doi.org/10.1016/j.econmod.2017.07.005

Pece, A. M. (2015). The connection between economic growth and stock markets. SEA - Practical Application of Science, III(7), 445-450.

Phillips, P. C. B and Perron, P. (1988). Testing for a unit root in time series regression. Biometrika, 75(2), 335-346. https://www.jstor.org/stable/2336182

Saafi, S., Bel Haj Mohamed, M. and Ben Doudou, M. (2016). Causal nexus between financial integration and economic growth: Does nonlinearity matter? Journal of Economic Integration, 31(4), 817-854. http://dx.doi.org/10.11130/jei.2016.31.4.817

Shaw, E. S. (1973). Financial deepening in economic development. New York: Oxford University Press.

Smith, G. (2012). The changing and relative efficiency of European emerging stock markets. The European Journal of Finance, 18(8), 689-708. https://doi.org/10.1080/1351847X.2011.628682

Stiglitz, J. and Weiss, A. (1981). Credit rationing in markets with imperfect information. The American Economic Review, 71(3), 393-410. https://www.jstor.org/stable/1802787

Tiwari, A. K., Mutascu, M. J., Albulescu, C. T. and Kyophilavong, P. (2015). Frequency domain causality analysis of stock market and economic activity in India. International Review of Economics \& Finance, 39, 224-238. http://dx.doi.org/10.1016/j.iref.2015.04.007

Toda, H. Y. and Yamamoto, T. (1995). Statistical inference in vector autoregressions with possibly integrated processes. Journal of Econometrics, 66(1-2), 225-250. http://dx.doi.org/10.1016/0304-4076(94)01616-8

Wachtel, P. (2003). How much do we really know about growth and finance? Federal Reserve Bank of Atlanta Economic Review, 88(1), 33-47. http://dx.doi.org/10.1016/0304-4076(94)01616-8 


\section{Annex 1: Country graphs}

\subsection{Bulgaria}

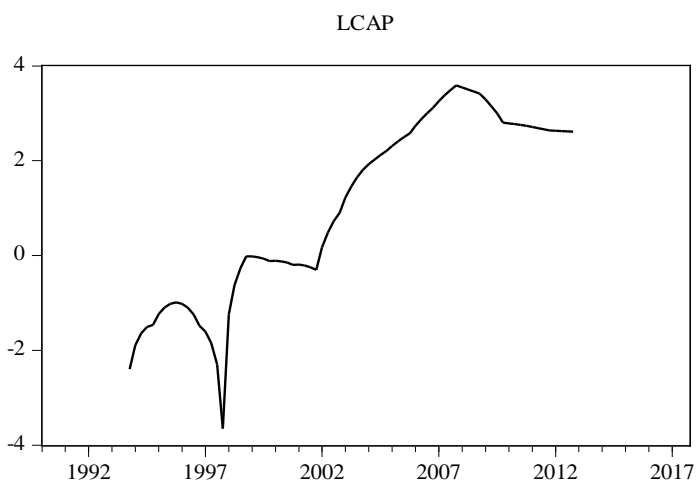

\subsection{Czechia}

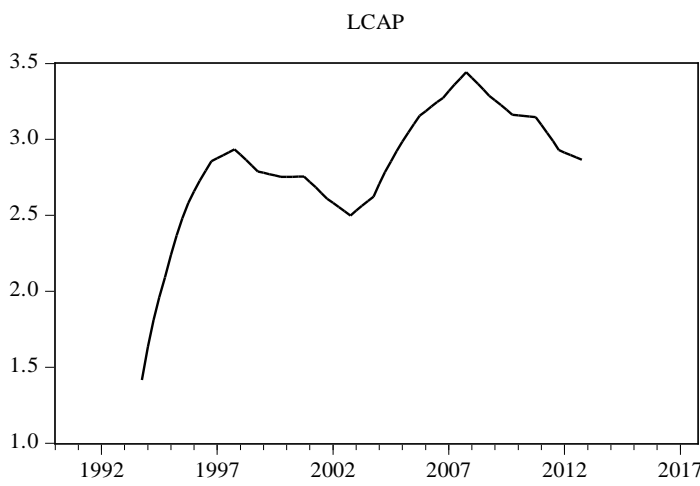

\subsection{Estonia}

LCAP

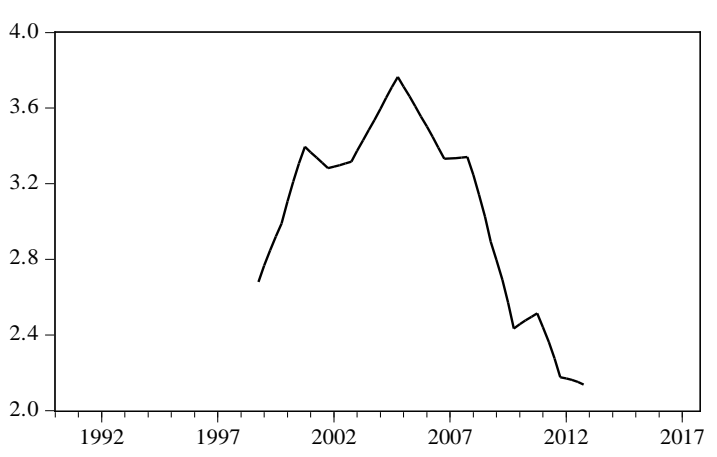

LGDP

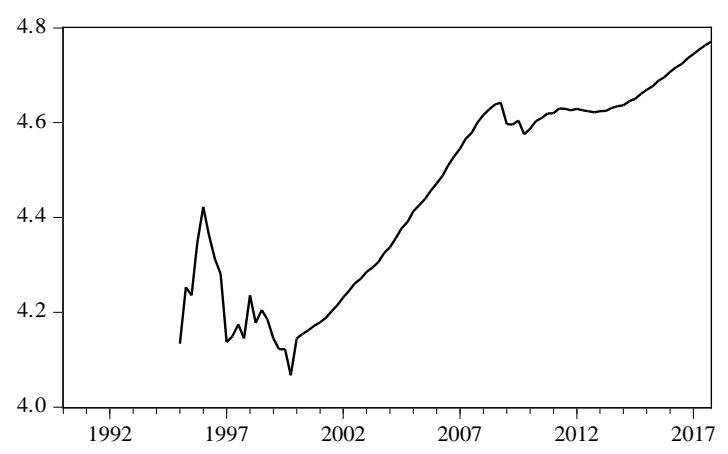

LGDP

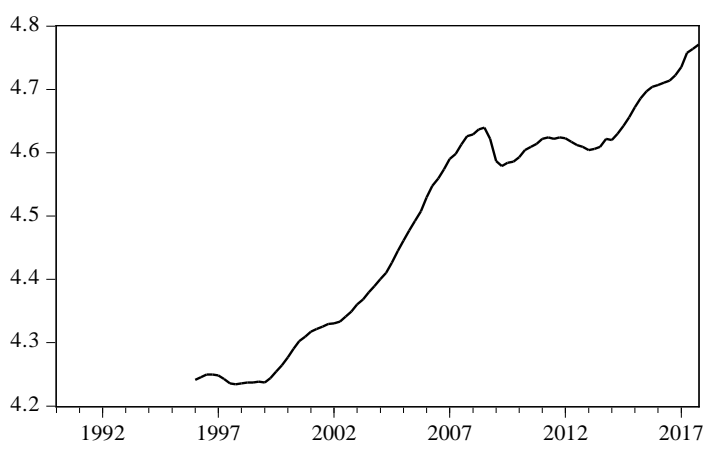

LGDP

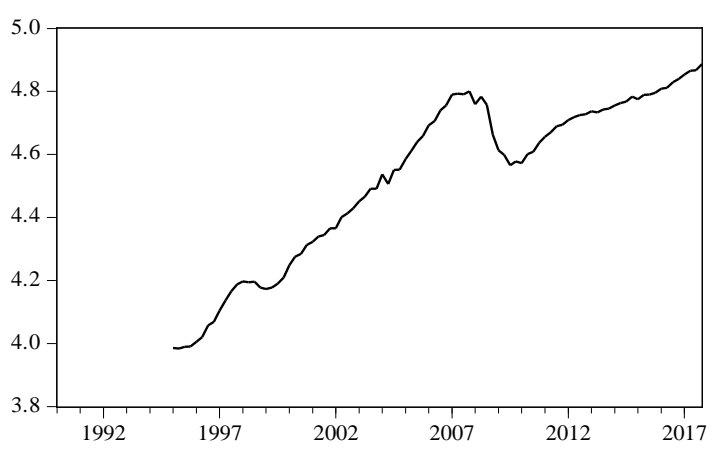




\subsection{Hungary}
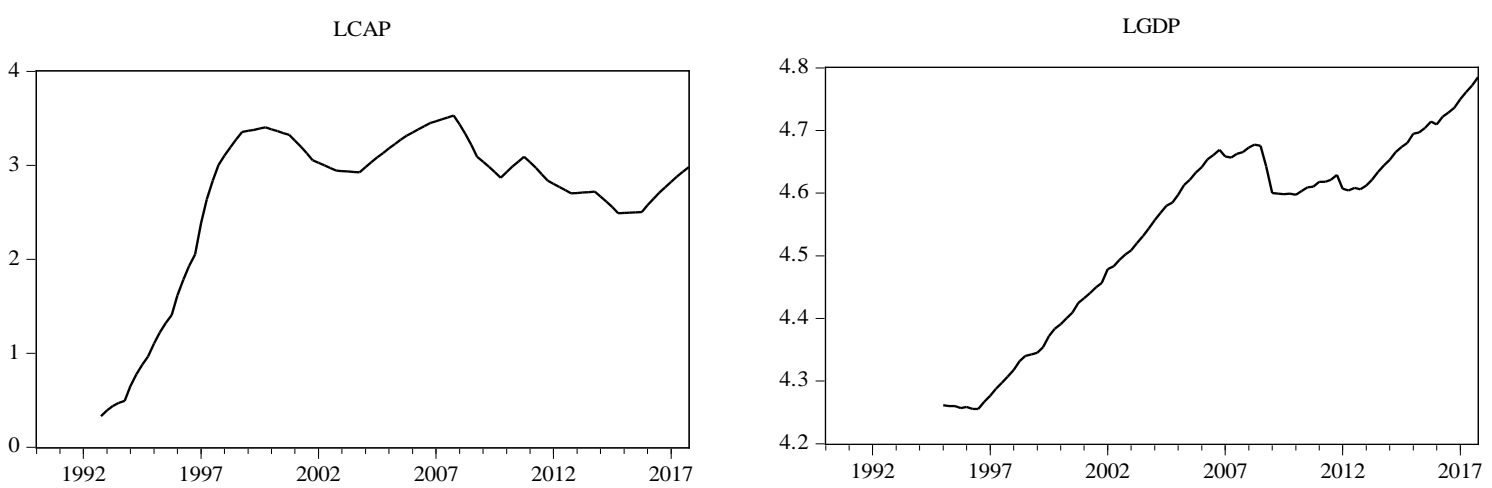

\subsection{Latvia}
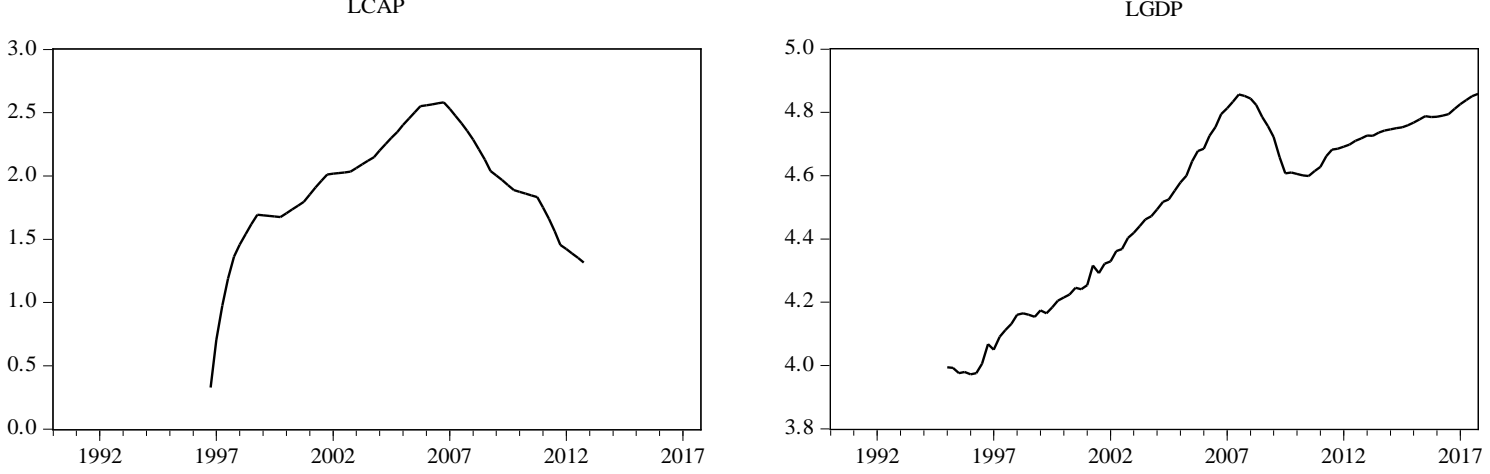

\subsection{Lithuania}

LCAP

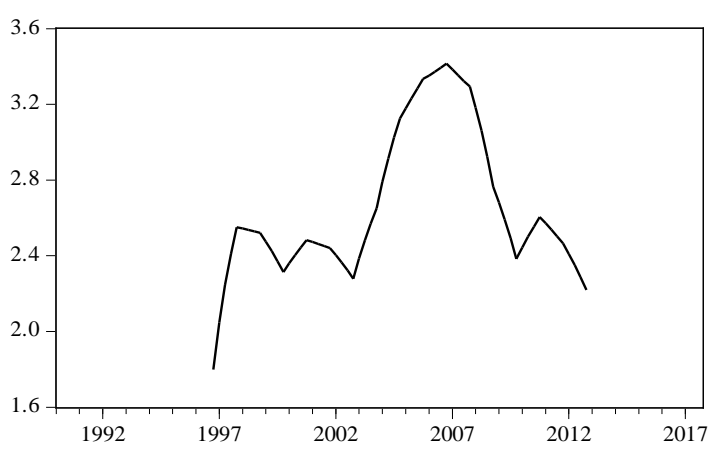

LGDP

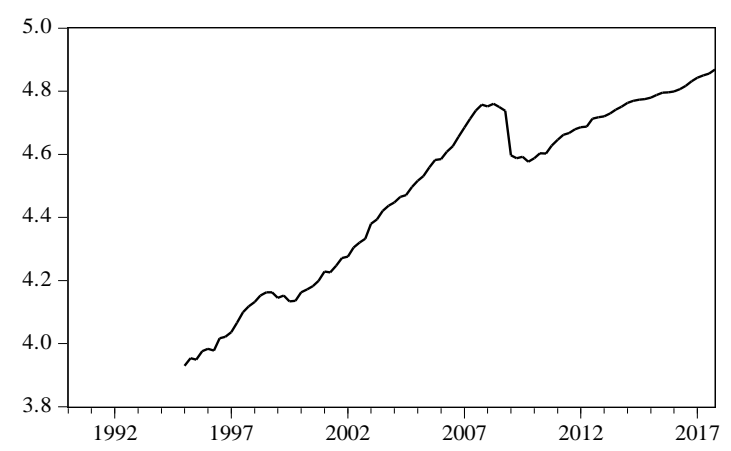




\subsection{Poland}
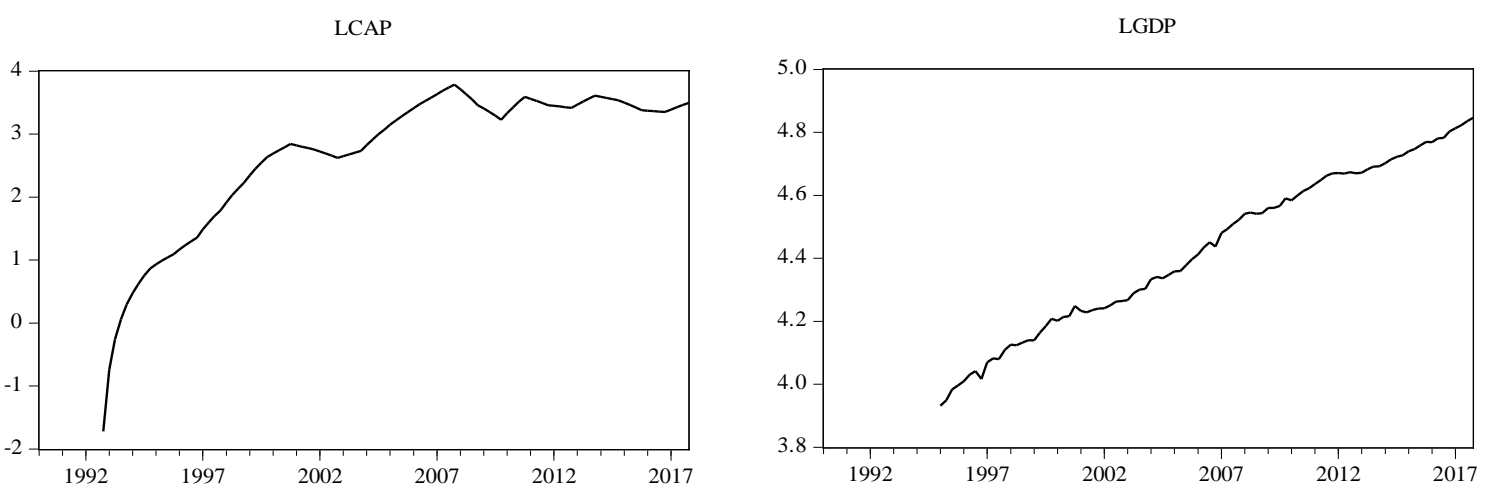

\subsection{Romania}
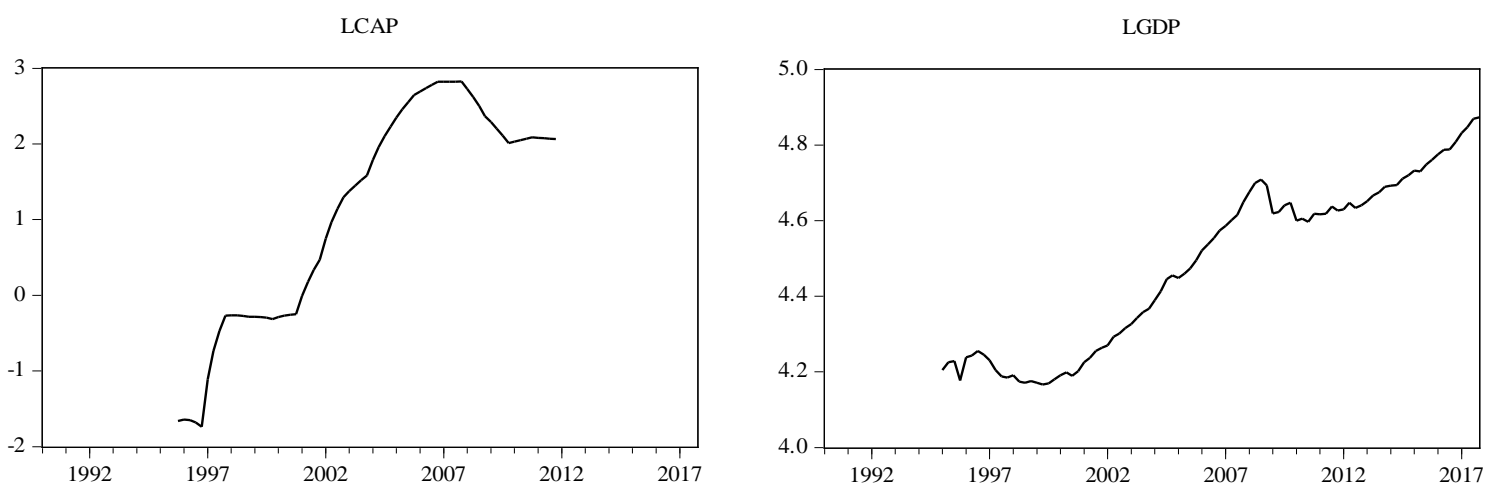

\subsection{Slovakia}
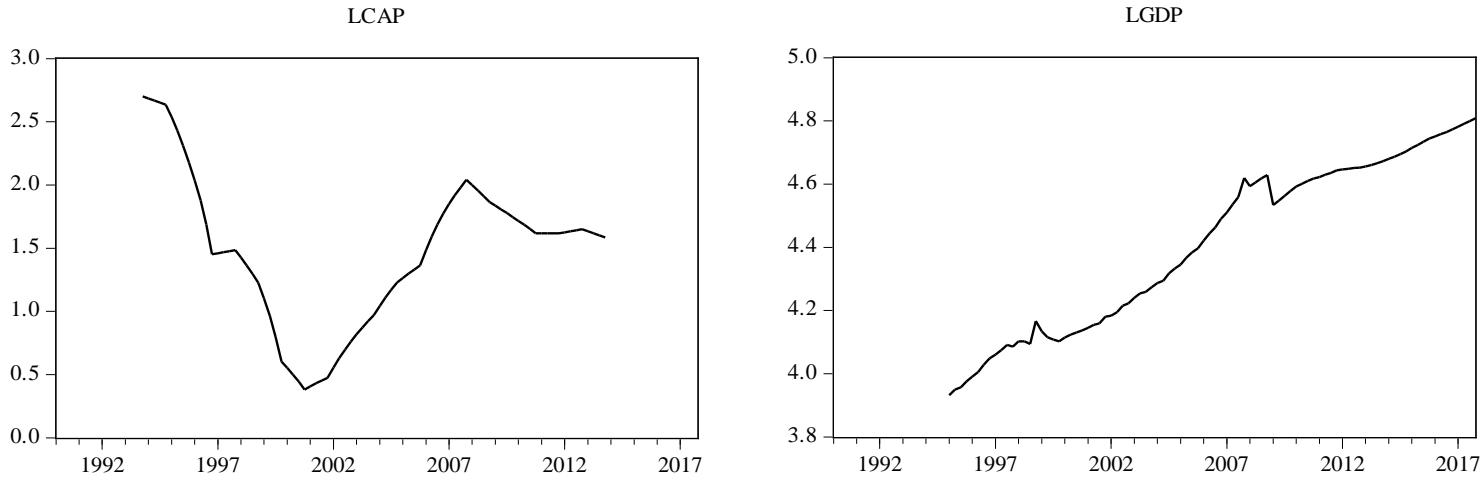


\subsection{Slovenia}
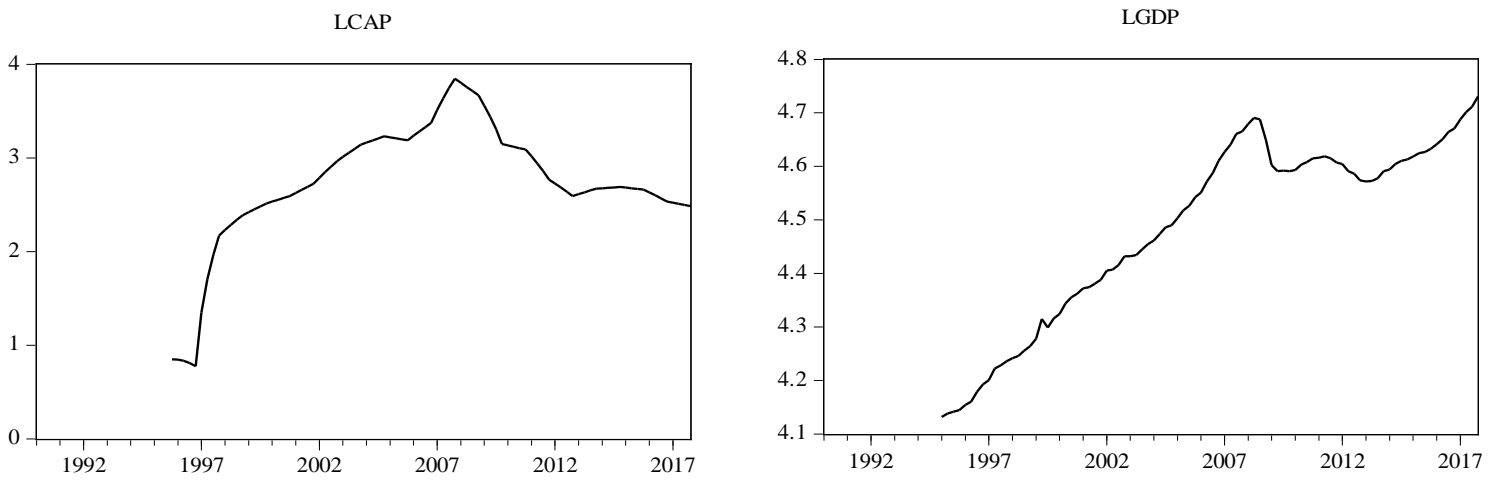

\section{Annex 2: Unit root test (Phillips-Perron test) and KPSS test}

2.1 Phillips-Perron test

\begin{tabular}{|c|c|c|c|c|c|}
\hline Country & Variable & t-Stat & Prob. & Data & Unit root \\
\hline \multirow[t]{4}{*}{ Bulgaria } & LGDP & -2.150155 & 0.5110 & Trend & \\
\hline & LCAP & -1.755856 & 0.7163 & Trend & LGDP: I(1) \\
\hline & $\Delta \mathrm{LGDP}$ & -9.827242 & $0.0000 *$ & 0 mean & LCAP: I(1) \\
\hline & $\Delta \mathrm{LCAP}$ & -8.436299 & $0.0000 *$ & 0 mean & \\
\hline \multirow[t]{4}{*}{ Czechia } & LGDP & -1.729401 & 0.7298 & Trend & \\
\hline & LCAP & -3.195202 & 0.0932 & Trend & LGDP: I(1) \\
\hline & $\Delta \mathrm{LGDP}$ & -2.948487 & 0.0036* & 0 mean & LCAP: I(1) \\
\hline & $\triangle \mathrm{LCAP}$ & -3.906734 & $0.0002 *$ & 0 mean & \\
\hline \multirow[t]{4}{*}{ Estonia } & LGDP & -1.695813 & 0.7453 & Trend & \\
\hline & LCAP & -0.216773 & 0.9298 & Constant & LGDP: I(1) \\
\hline & $\Delta \mathrm{LGDP}$ & -6.447840 & $0.0000 *$ & 0 mean & LCAP: I(1) \\
\hline & $\triangle \mathrm{LCAP}$ & -2.578064 & $0.0108^{* *}$ & 0 mean & \\
\hline \multirow{4}{*}{ Hungary } & LGDP & -1.308612 & 0.8796 & Trend & \\
\hline & LCAP & -2.391948 & 0.3815 & Trend & LGDP: I(1) \\
\hline & $\Delta \mathrm{LGDP}$ & -4.112357 & $0.0001 *$ & 0 mean & LCAP: I(1) \\
\hline & $\triangle \mathrm{LCAP}$ & -2.464738 & $0.0140 * *$ & 0 mean & \\
\hline \multirow[t]{4}{*}{ Latvia } & LGDP & -1.410266 & 0.8516 & Trend & \\
\hline & LCAP & -2.792841 & 0.2053 & Trend & LGDP: I(1) \\
\hline & $\triangle \mathrm{LGDP}$ & -5.717847 & $0.0000^{*}$ & 0 mean & LCAP: I(1) \\
\hline & $\triangle \mathrm{LCAP}$ & -5.660983 & $0.0000^{*}$ & 0 mean & \\
\hline \multirow[t]{4}{*}{ Lithuania } & LGDP & -1.631983 & 0.7726 & Trend & \\
\hline & LCAP & -2.184319 & 0.2139 & Constant & LGDP: I(1) \\
\hline & $\Delta \mathrm{LGDP}$ & -6.618819 & $0.0000 *$ & 0 mean & LCAP: I(1) \\
\hline & $\triangle \mathrm{LCAP}$ & -3.470282 & $0.0008^{*}$ & 0 mean & \\
\hline \multirow[t]{4}{*}{ Poland } & LGDP & -2.947297 & 0.1530 & Trend & \\
\hline & LCAP & -5.504325 & $0.0001 *$ & Trend & LGDP: I(1) \\
\hline & $\Delta \mathrm{LGDP}$ & -7.807336 & $0.0000 *$ & 0 mean & LCAP: I(0) \\
\hline & $\triangle \mathrm{LCAP}$ & -10.23882 & $0.0000^{*}$ & 0 mean & \\
\hline
\end{tabular}


Economics: The Open-Access, Open-Assessment E-Journal 14 (2020-17)

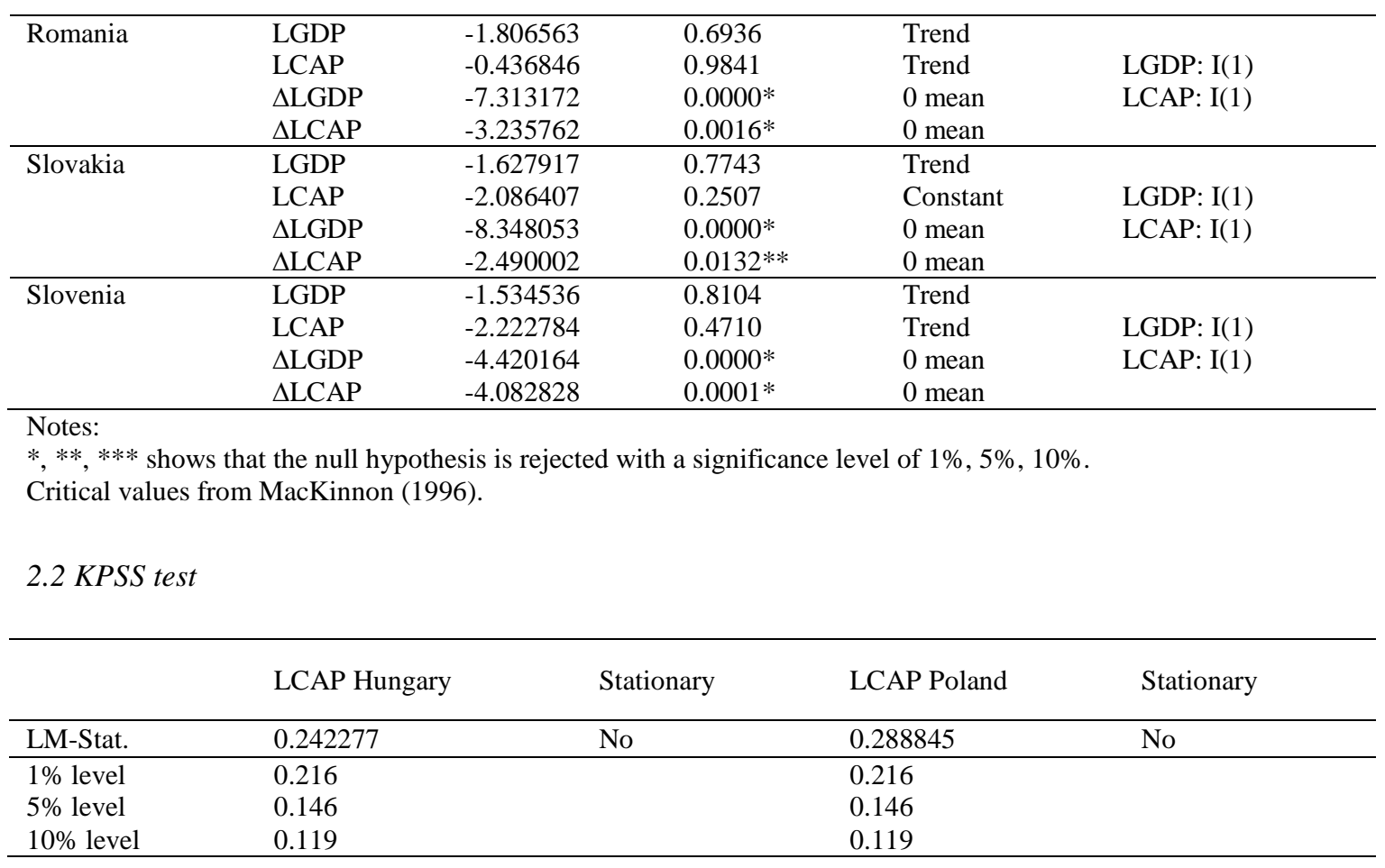




\section{Annex 3: Johansen cointegration test}

\begin{tabular}{|c|c|c|c|c|}
\hline Country & $\begin{array}{l}\text { Hypothesized } \\
\text { No. of CE(s) }\end{array}$ & $\begin{array}{l}\text { Prob. } \\
\text { Unrestricted } \\
\text { Cointegration Rank Test } \\
\text { (Trace) }\end{array}$ & $\begin{array}{l}\text { Prob. } \\
\text { Unrestricted } \\
\text { Cointegration Rank Test } \\
\text { (Maximum Eigenvalue) }\end{array}$ & Cointegration \\
\hline \multirow[t]{2}{*}{ Bulgaria } & None ${ }^{(i)(i i)}$ & 0.0000 & 0.0000 & $(\mathrm{~A}),(\mathrm{C})$ \\
\hline & At most 1 & 0.0585 & 0.0585 & \\
\hline \multirow[t]{2}{*}{ Czechia } & None & 0.1727 & 0.3832 & (B), (D) \\
\hline & At most 1 & 0.0535 & 0.0535 & \\
\hline \multirow[t]{2}{*}{ Estonia } & None & 0.0805 & 0.0737 & (B), (D) \\
\hline & At most 1 & 0.4658 & 0.4658 & \\
\hline \multirow[t]{2}{*}{ Hungary } & None ${ }^{\text {(i) (ii) }}$ & 0.0373 & 0.0250 & $(\mathrm{~A}),(\mathrm{C})$ \\
\hline & At most 1 & 0.6584 & 0.6584 & \\
\hline \multirow[t]{2}{*}{ Latvia } & None ${ }^{(i)(i i)}$ & 0.0143 & 0.0088 & $(\mathrm{~A}),(\mathrm{C})$ \\
\hline & At most 1 & 0.4972 & 0.4972 & \\
\hline \multirow[t]{2}{*}{ Lithuania } & None & 0.8425 & 0.7271 & (B), (D) \\
\hline & At most 1 & 0.9235 & 0.9235 & \\
\hline \multirow[t]{2}{*}{ Poland } & None & 0.3190 & 0.2453 & (B), (D) \\
\hline & At most 1 & 0.9477 & 0.9477 & \\
\hline \multirow[t]{2}{*}{ Romania } & None ${ }^{\text {(i) (ii) }}$ & 0.0182 & 0.0369 & (A), (C) \\
\hline & At most 1 & 0.0722 & 0.0722 & \\
\hline \multirow[t]{2}{*}{ Slovakia } & None ${ }^{\text {(ii) }}$ & 0.0617 & 0.0326 & (C) \\
\hline & At most 1 & 0.6730 & 0.6730 & \\
\hline \multirow[t]{2}{*}{ Slovenia } & None ${ }^{\text {(i) (ii) }}$ & 0.0348 & 0.0225 & $(\mathrm{~A}),(\mathrm{C})$ \\
\hline & At most 1 & 0.7299 & 0.7299 & \\
\hline
\end{tabular}

Notes:

(i) Denotes rejection of the hypothesis at the 0.05 level (Trace test).

(ii) Denotes rejection of the hypothesis at the 0.05 level (Max-Eigenvalue test).

(A) Trace test indicates 1 cointegrating eqn(s) at the 0.05 level.

(B) Trace test indicates no cointegration at the 0.05 level.

(C) Max-Eigenvalue test indicates 1 cointegrating eqn(s) at the 0.05 level.

(D) Max-Eigenvalue test indicates no cointegration at the 0.05 level.

Critical values from MacKinnon-Haug-Michelis (1999). 


\section{Annex 4: Causality graphs from the Frequency Domain approach}

\subsection{Bulgaria}

Causality in the frequency domain | Ho: There is not causality at frequency Omega | P-value D.F. $(2,36) \mid$ Selected lag: 12 | Exogenous variables: c
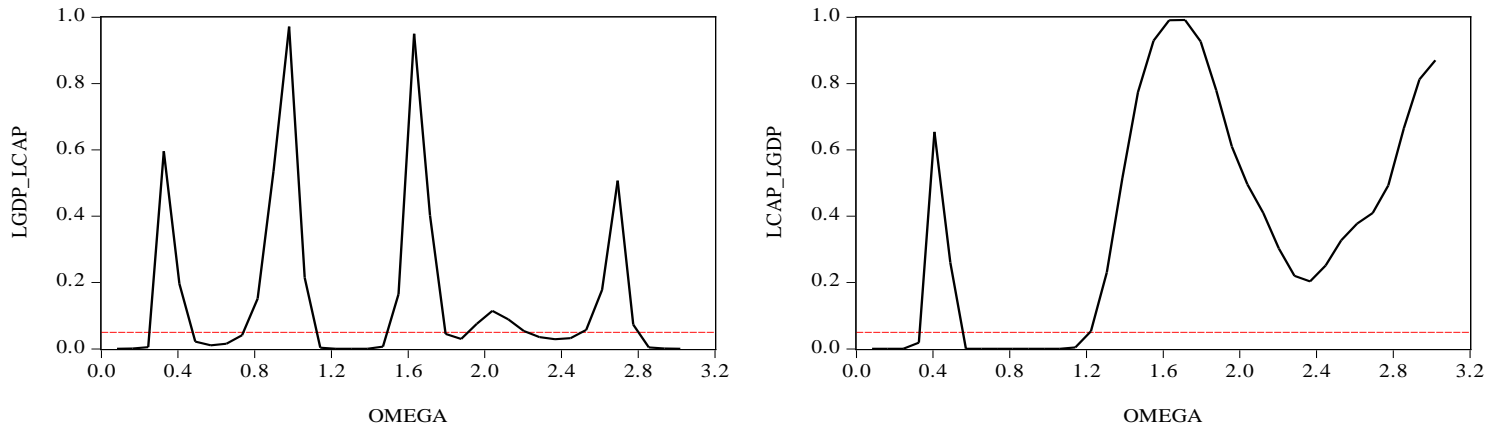

4.2 Czechia

Causality in the frequency domain | H0: There is not causality at frequency Omega | P-value D.F. $(2,19)$ | Selected lag: 16 | Exogenous variables: $\mathrm{c}$
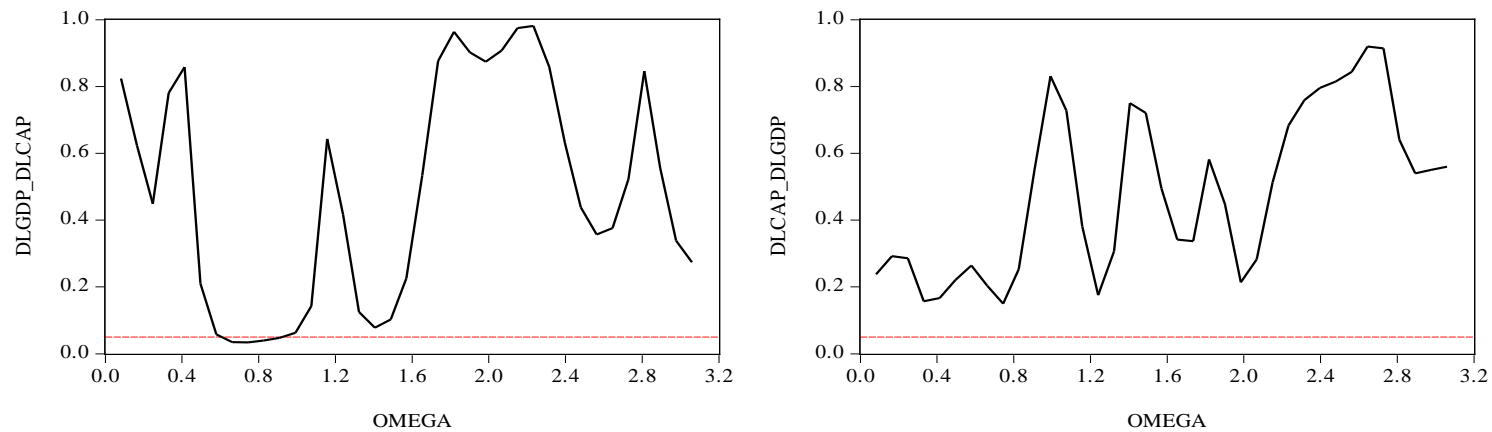

\subsection{Estonia}

Causality in the frequency domain | H0: There is not causality at frequency Omega | P-value D.F. $(2,35)$ | Selected lag: 7 | Exogenous variables: c
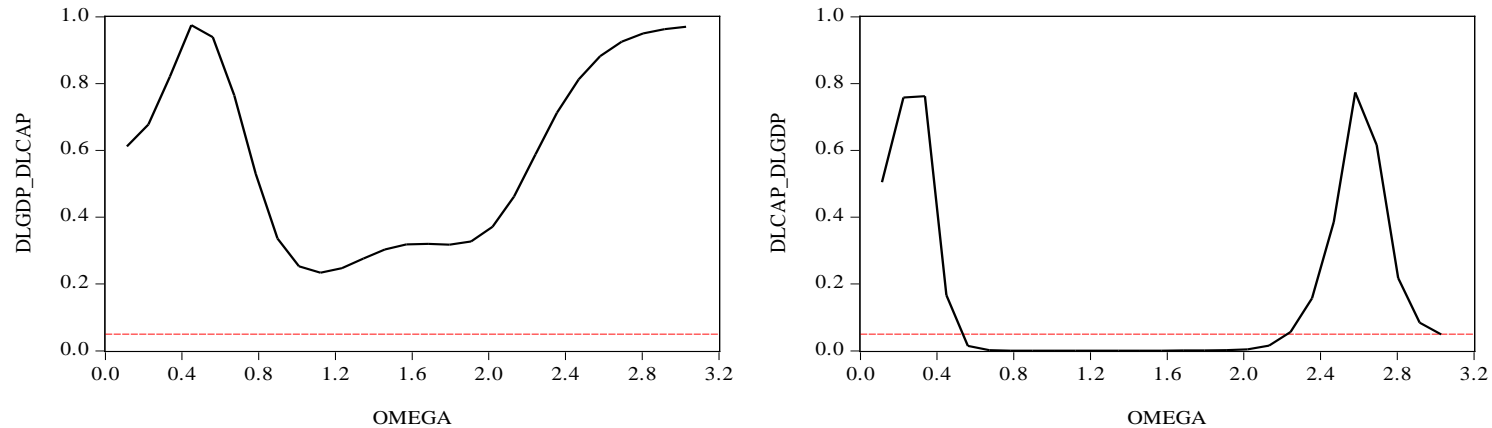
Economics: The Open-Access, Open-Assessment E-Journal 14 (2020-17)

\subsection{Hungary}
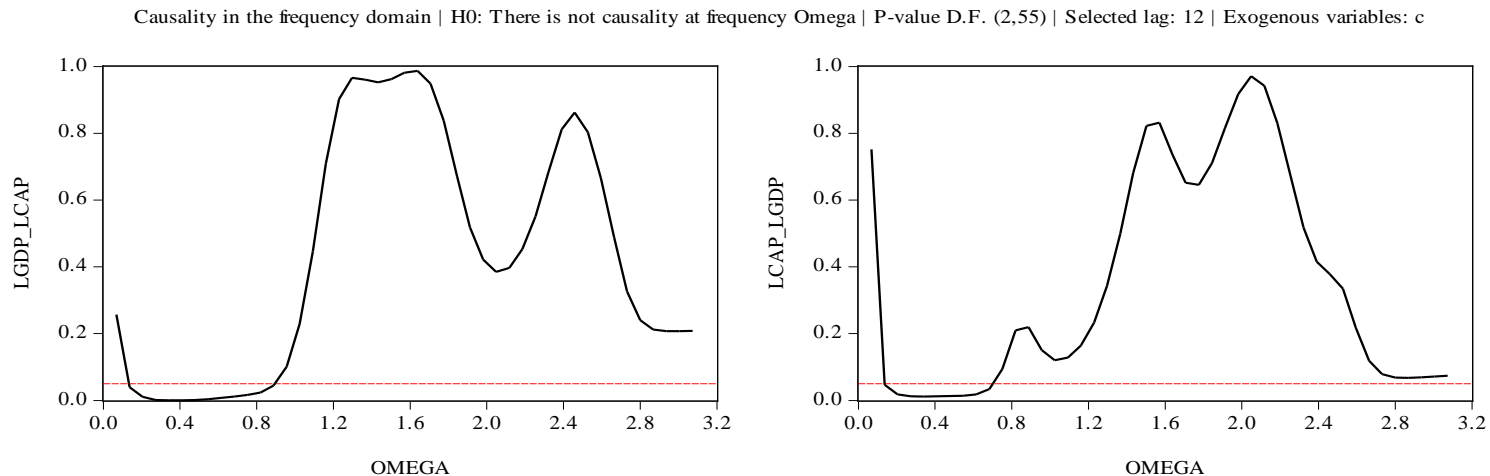

\subsection{Latvia}

Causality in the frequency domain | H0: There is not causality at frequency Omega | P-value D.F. (2,29) | Selected lag: 12 | Exogenous variables: $\mathrm{c}$
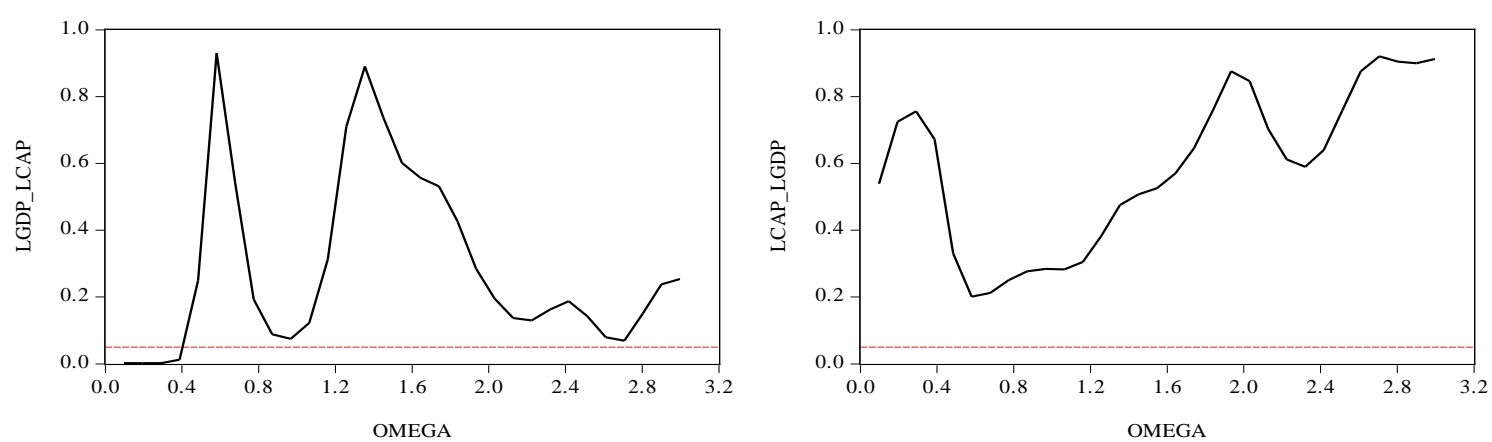

\subsection{Lithuania}

Causality in the frequency domain | H0: There is not causality at frequency Omega | P-value D.F. $(2,10)$ | Selected lag: 18 | Exogenous variables: c
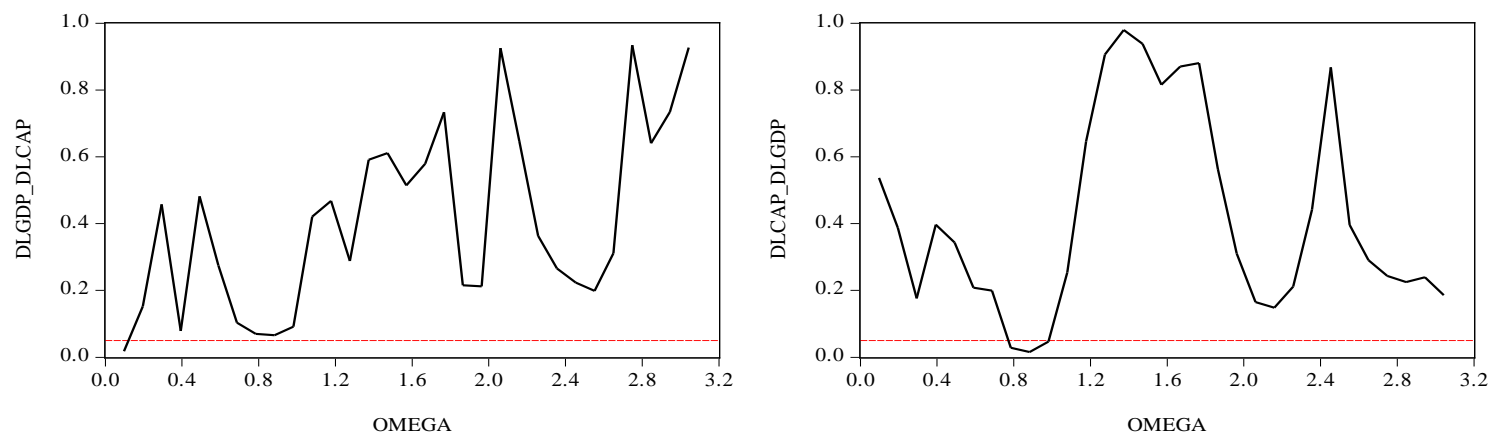


\subsection{Poland}
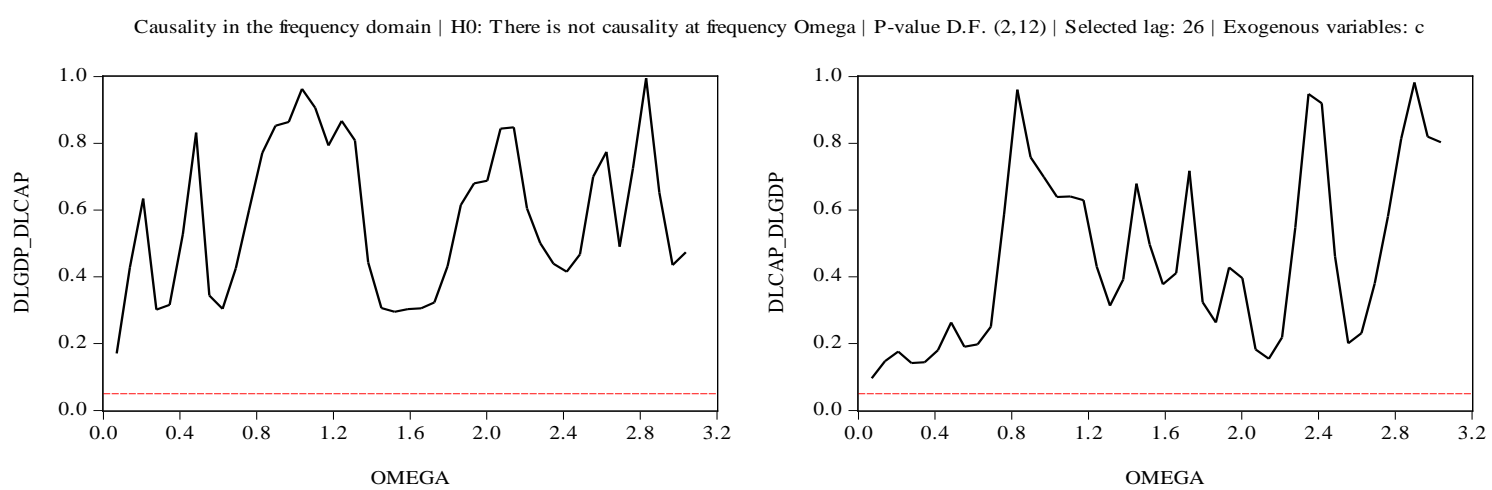

\subsection{Romania}

Causality in the frequency domain | H0: There is not causality at frequency Omega | P-value D.F. $(2,47) \mid$ Selected lag: 6 | Exogenous variables: c
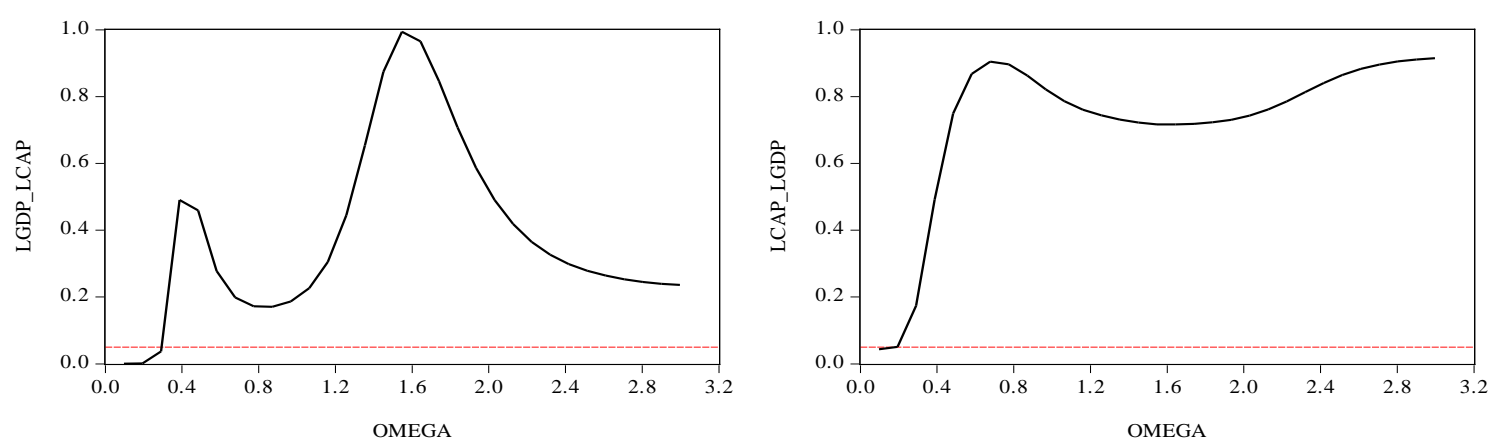

\subsection{Slovakia}

Causality in the frequency domain | Ho: There is not causality at frequency Omega | P-value D.F. $(2,46) \mid$ Selected lag: 10 | Exogenous variables:
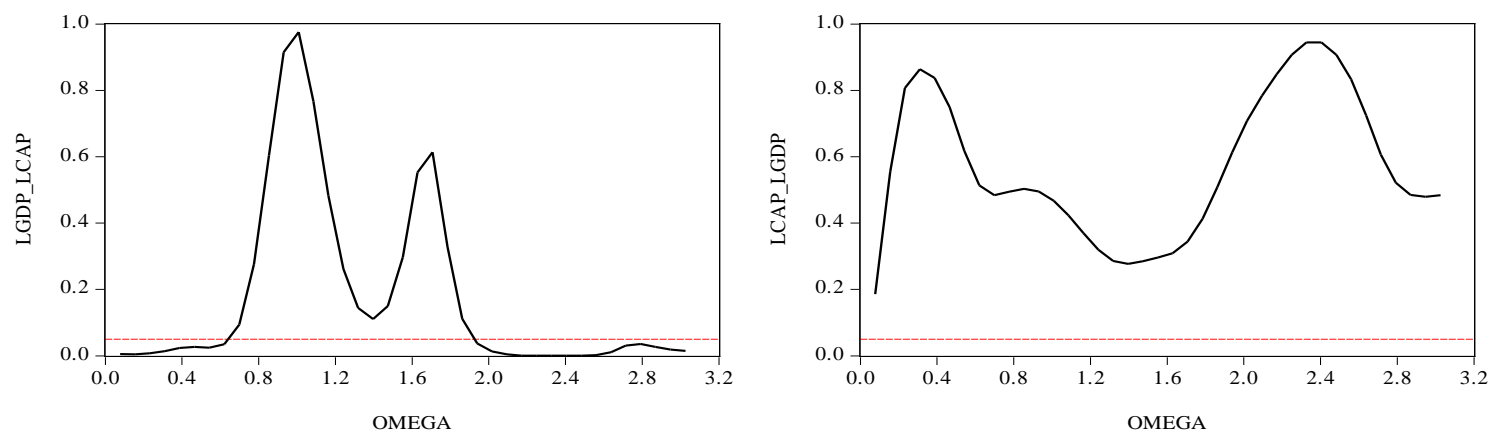
Economics: The Open-Access, Open-Assessment E-Journal 14 (2020-17)

\subsection{Slovenia}

Causality in the frequency domain | Ho: There is not causality at frequency Omega | P-value D.F. $(2,52) \mid$ Selected lag: 12 | Exogenous variables: c
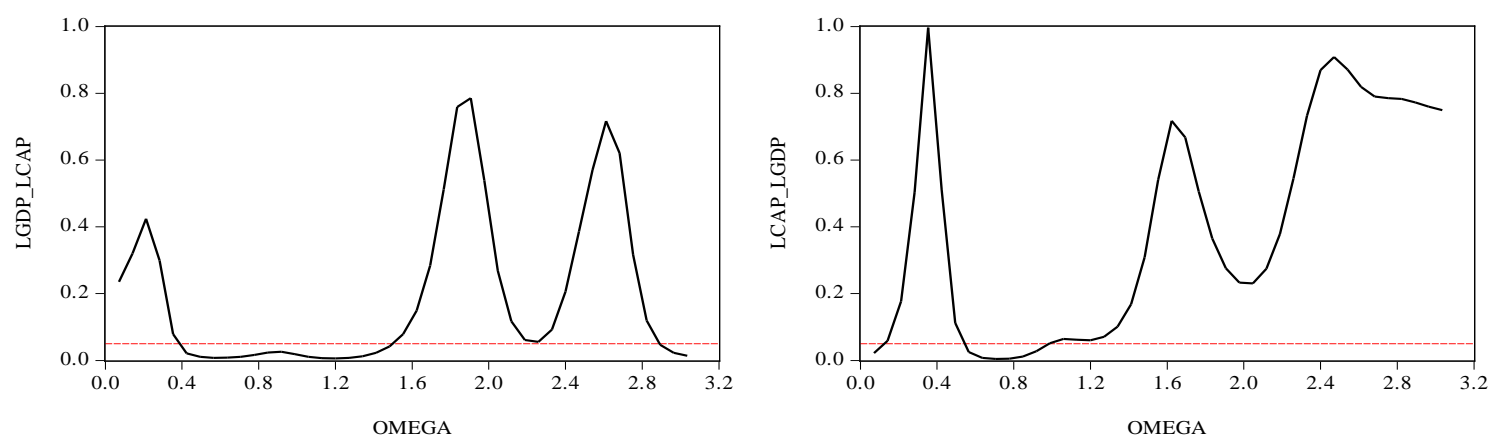